\title{
Studies of mice deleted for Sox3 and uc482: relevance to $\mathrm{X}$-linked hypoparathyroidism
}

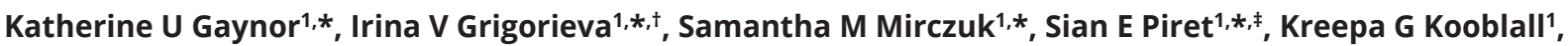 \\ Mark Stevenson ${ }^{1}$, Karine Rizzoti ${ }^{2}$, Michael R Bowl ${ }^{1,5}$, M Andrew Nesbit $^{1} \|$, Paul T Christie ${ }^{1}$, William D Fraser ${ }^{3}$, \\ Tertius Hough ${ }^{4}$, Michael P Whyte ${ }^{5}$, Robin Lovell-Badge ${ }^{2}$ and Rajesh V Thakker $^{1}$
}

${ }^{1}$ Academic Endocrine Unit, Radcliffe Department of Medicine, University of Oxford, Oxford Centre for Diabetes, Endocrinology and Metabolism, Churchill Hospital, Oxford, UK

${ }^{2}$ The Francis Crick Institute, London, UK

${ }^{3}$ Norwich Medical School, Faculty of Medicine and Health Sciences, University of East Anglia, Norwich, UK

${ }^{4}$ MRC Mammalian Genetics Unit, MRC Harwell Institute, Harwell Science and Innovation Campus, Oxfordshire, UK

${ }^{5}$ Washington University in St Louis School of Medicine, Center for Metabolic Bone Disease and Molecular Research, St Louis, Missouri, USA

Correspondence should be addressed to R V Thakker: rajesh.thakker@ndm.ox.ac.uk

*(K U Gaynor, I V Grigorieva, S M Mirczuk and S E Piret contributed equally to this work)

${ }^{\dagger}(\mathrm{I} \vee$ Grigorieva is now at Wales Kidney Research Unit, Systems Immunity University Research Institute, Division of Infection and Immunity, College of Biomedical and Life Sciences, Cardiff University, Heath Park, Cardiff, UK)

${ }^{\ddagger}$ (S E Piret is now at Department of Medicine, Stony Brook University, Stony Brook, New York, USA)

${ }^{\S}$ (M R Bowl is now at MRC Mammalian Genetics Unit, MRC Harwell Institute, Harwell Science and Innovation Campus, Oxfordshire, UK)

"(M Andrew Nesbit is now at School of Biomedical Sciences, Biomedical Sciences Research Institute, Ulster University, Cromore Road, Coleraine, Co. Londonderry, UK)

\begin{abstract}
Hypoparathyroidism is genetically heterogeneous and characterized by low plasma calcium and parathyroid hormone (PTH) concentrations. X-linked hypoparathyroidism (XLHPT) in two American families is associated with interstitial deletion-insertions involving deletions of chromosome Xq27.1 downstream of SOX3 and insertions of predominantly non-coding DNA from chromosome 2p25.3. These could result in loss, gain, or movement of regulatory elements, which include ultraconserved element uc482, which could alter SOX3 expression. To investigate this, we analysed SOX3 expression in EBV-transformed lymphoblastoid cells from three affected males, three unaffected males, and four carrier females from one XLHPT family. SOX3 expression was similar in all individuals, indicating that the spatiotemporal effect of the interstitial deletion-insertion on SOX3 expression postulated to occur in developing parathyroids did not manifest in lymphoblastoids. Expression of SNTG2, which is duplicated and inserted into the X chromosome, and ATP11C, which is moved telomerically, were also similarly expressed in all individuals. Investigation of male

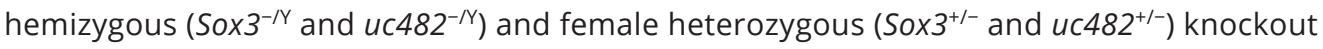
mice, together with wild-type littermates (male Sox $3^{+/ \gamma}$ and $u c 482^{+/ \gamma}$, and female Sox $3^{+/+}$ and $u\left(482^{+/+}\right)$, revealed $\operatorname{Sox}^{-/ Y}$, Sox $3^{+/-}, u c 482^{-} / Y$, and $u c 482^{+/-}$mice to have normal plasma biochemistry, compared to their respective wild-type littermates. When challenged with a low calcium diet, all mice had hypocalcaemia, and elevated plasma PTH concentrations and alkaline phosphatase activities, and $50 \times 3^{-N}, S_{0 \times 3^{+/-}}, u c 482^{-N}$, and $u c 482^{+/-}$mice had similar plasma biochemistry, compared to wild-type littermates. Thus, these results indicate that absence of Sox3 or uc482 does not cause hypoparathyroidism and that XLHPT likely reflects a more complex mechanism.
\end{abstract}

\section{Key Words}

- parathyroid-related disorders

- transcription factors

- genetic research

- genetic animal models

- preclinical studies https://ec.bioscientifica.com https://doi.org/10.1530/EC-19-0478 (c) 2020 The authors Published by Bioscientifica Ltd

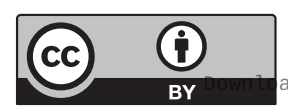

This work is licensed under a Creative Commons Attribution 4.0 International License. ded from Bioscientifica.com at 04/26/2023 01:31:31PM
Endocrine Connections (2020) 9, 173-186 


\section{Introduction}

Heritable hypoparathyroidism (HPT) is a genetically heterogeneous disease, characterized biochemically by hypocalcaemia, hyperphosphatemia, low plasma parathyroid hormone (PTH) concentrations and inappropriately normal or high urinary calcium excretion (1). Genetic abnormalities causing HPT may lead to complex congenital syndromes or to an isolated endocrinopathy, for which autosomal dominant, autosomal recessive and X-linked modes of inheritance have been described (OMIM \#146200 and \%307700) (2). These genetic abnormalities may result in defects in PTH itself, parathyroid gland development, or parathyroid gland function. For example, mutations in PTH cause a lack of functional PTH protein (3), mutations in the parathyroid-specific transcription factor glial cells missing B $(G C M B)$ result in defective parathyroid gland development $(4,5)$, and gain-of-function mutations in the calcium-sensing receptor (CaSR) may suppress parathyroid gland function in association with hypocalcaemia (6).

X-linked HPT (XLHPT, OMIM \%307700) was first reported in 1960 (7) in a large kindred from Missouri (MO), USA and subsequently in a related family also from MO $(8,9,10)$, and more recently in a third, unrelated family from Illinois (IL), USA (11). Both families from MO and the family from IL had interstitial deletioninsertions involving deletion of a non-coding region on chromosome Xq27.1 between sex-determining region $\mathrm{Y}$ (SRY)-box 3 (SOX3) and adenosine triphosphatase 11C $(A T P 11 C)$, and an insertion of a larger section emanating from chromosome 2p25.3 $(8,11)$ (Fig. 1A). In the MO kindred, this consisted of a $\sim 25 \mathrm{~kb}$ deletion of non-coding DNA from Xq27.1 $\sim 67 \mathrm{~kb}$ downstream of SOX3 and an inverted insertion of $\sim 340 \mathrm{~kb}$ containing exons $2-16$ of syntrophin gamma 2 (SNTG2) from 2p25.3 (8) (Fig. 1A). In the IL family, $\sim 1.5 \mathrm{~kb}$ was deleted from Xq27.1 80 kb downstream of SOX3 and $\sim 47 \mathrm{~kb}$ of non-coding DNA was inserted from $2 \mathrm{p} 25.3$, which differed from the inserted DNA in the MO kindred (11) (Fig. 1A). Although the 340 $\mathrm{kb}$ insertion in the MO kindred contained 15 exons of SNTG2, no open reading frames were present (8), and the $47 \mathrm{~kb}$ insertion in the IL family did not contain coding DNA. Similarly, neither of the X chromosome deletions removed coding DNA. We therefore hypothesized that these rearrangements may alter the function of a regulatory element or nearby gene, that affects SOX3 expression, which has been demonstrated in developing mouse parathyroids between embryonic day (E)10.5 and

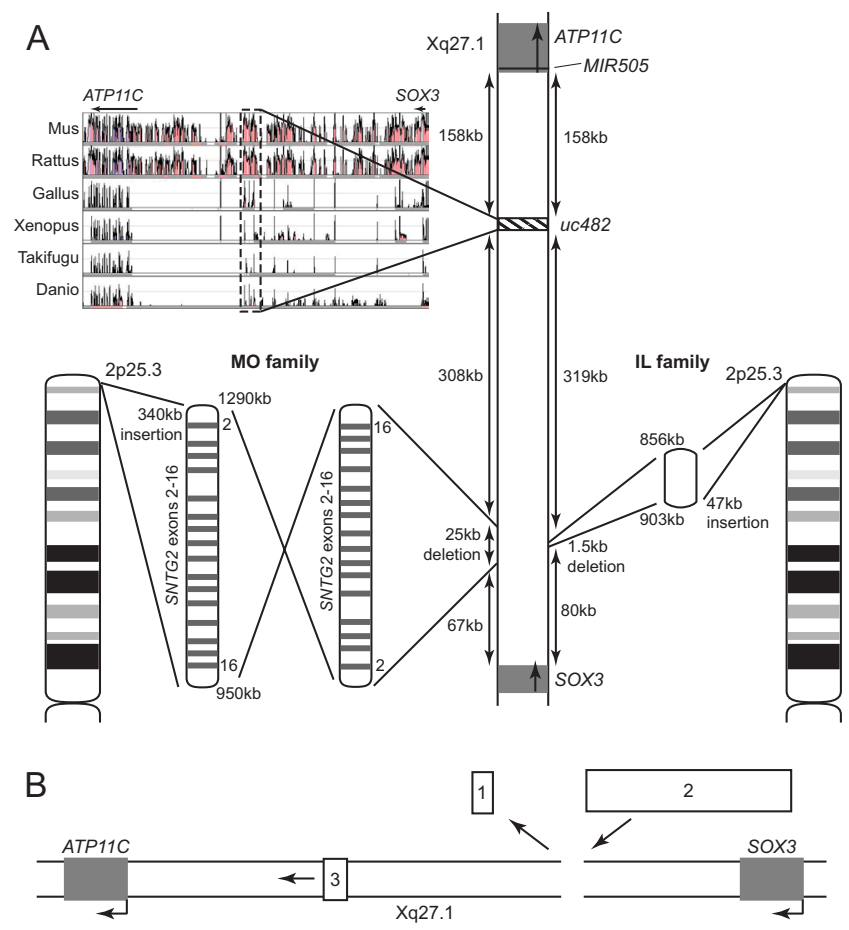

Figure 1

Chromosomal rearrangements associated with XLHPT. (A) Unrelated families from Missouri (MO) and Illinois (IL), USA, have interstitial deletion-insertions involving chromosome Xq27.1 and chromosome 2 25.3. In the MO kindred, a $25 \mathrm{~kb}$ Xq27.1 deletion is replaced by a 340 $\mathrm{kb}$ inverted insertion containing exons 2-16 of syntrophin gamma 2 (SNTG2). In the IL family, a $1.5 \mathrm{~kb}$ Xq27.1 deletion is replaced by a $47 \mathrm{~kb}$ 2 p25.3 insertion that does not contain any coding DNA. These deletioninsertions occur downstream of sex-determining region $Y(S R Y)$-box 3 (SOX3) and upstream of adenosine triphosphatase 11C (ATP11C) and the ultraconserved element uc482. uc482 is a genome region conserved from human through mouse (Mus), rat (Rattus), chicken (Gallus), frog (Xenopus), and puffer fish (Takifugu) to zebrafish (Danio) (plotted using Vista Browser). MIR505 (chromosomal location 139,924,148-139,924,231 (GRCh38/hg38)) is located within the first intron in two of the nine ATP11C (chromosomal location 139,726,346-139,945,276 (GRCh38/hg38)) transcripts and upstream of the remaining seven transcripts, five of which are protein-coding. (B) Three possible mechanisms by which the XLHPT deletion-insertions may alter SOX3 expression are (1) loss of an enhancer or repressor (represented by box 1) from Xq27.1; (2) gain of an enhancer or repressor (represented by box 2) from 2p25.3; or (3) movement of an enhancer or repressor (represented by box 3) away from SOX3, as the insertion is larger than the deletion.

E15.5 (8). SOX3 expression was reported to be altered by a large $774 \mathrm{~kb}$ insertion downstream of SOX3 in patients with XX male sex reversal, demonstrating that SOX3 expression may be susceptible to position effects, similar to those reported for SOX9 and $S R Y(12,13)$, although SOX3-coding mutations have not been identified in male patients with HPT (14).

Thus, in the XLHPT families there are three possible mechanisms that could result in such alterations in SOX3

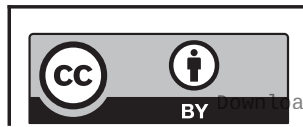

This work is licensed under a Creative Commons Attribution 4.0 International License. ded from Bioscientifica.com at 04/26/2023 01:31:31PM 
expression (Fig. 1B). Firstly, deletions of X chromosome sequences may result in loss of a repressor or enhancer of SOX3 expression. Secondly, insertions of chromosome 2 sequences may result in insertion of DNA that may repress or enhance SOX3 expression. Thirdly, deletioninsertions, that result in a net gain of DNA on the $\mathrm{X}$ chromosome, may move a repressor or enhancer of SOX3 expression further away from SOX3, thereby altering its effect on SOX3 expression, that is, a position effect (Fig. 1B). Gene enhancers and repressors are often evolutionarily conserved, and $>60 \%$ of ultraconserved (uc) non-coding elements that are conserved in human through to Takifugu rubripes (puffer fish), may act as positive enhancers (15). One such element, designated uc482 (or highly conserved non-coding element (HCNE) 8 ), is located $\sim 400 \mathrm{~kb}$ downstream of SOX3 and was reported to be a likely enhancer of Sox 3 expression in Danio rerio (zebrafish) (16). Furthermore, uc482 is moved further away from SOX3 by both of the deletion-insertions causing XLHPT (Fig. 1B).

To explore the possible roles of SOX3 and uc482 in HPT, we undertook studies to determine the effects of the interstitial deletion-insertion on SOX3 expression in patients with XLHPT and in knock-out mice lacking alleles of Sox3 and $u c 482$.

\section{Materials and methods}

\section{Human studies}

Venous blood samples were collected after informed consent from individuals and following protocols approved by local and national ethics committees (Multicentre Research Ethics Committee (London, UK; MREC 02/2/93) and the Human Research Protections Office, Washington University School of Medicine, St. Louis, MO, USA).

\section{DNA sequence analysis}

DNA was extracted from leukocytes using the Gentra Puregene blood kit (Qiagen) and standard protocols. PCR amplification of DNA across the deletion-insertion boundaries was carried out using primers previously described (8), and Sanger DNA sequence analysis was performed using the BigDye Terminator v3.1 Cycle Sequencing Kit (Life Technologies) and an ABI automated capillary sequencer (Applied Biosystems), as described $(4,8)$.

\section{Quantitative real-time PCR (qRT-PCR)}

Lymphocytes were Epstein-Barr virus (EBV)-transformed to generate a lymphoblastoid cell line as previously described (3), and mRNA extracted using the Oligotex mRNA mini kit (Qiagen) and standard protocols. cDNA was generated using Quantiscript reverse transcriptase (Qiagen), and quantitative reverse transcriptase (qRT)-PCRs performed using the QuantiTect SYBR Green PCR kit (Qiagen) in quadruplicate for each individual, and SOX3, SNTG2, ATP11C, and GAPDH specific primers, using a Rotorgene 5 (Qiagen), as described (17). Expression of genes was normalized to GAPDH expression and analyzed by the comparative $\Delta \Delta \mathrm{C}_{\mathrm{T}}$ method (18).

\section{Mouse studies}

All animal studies were approved by the University of Oxford Ethical Review Committee and were licensed (project license numbers PPL 30/2241, PPL 30/2739 and PPL 30/3251) under the Animals (Scientific Procedures) Act 1986, issued by the UK Government Home Office. Sox3-knockout mice were maintained on the MF1 outbred background (19) and uc482-knockout mice were maintained on the C57Bl/6 background (20). Mice were genotyped using DNA extracted from ear biopsies followed by PCR assay. PCR primers for Sox3 genotyping were WT F: 5'-TCGGGTGGTGGGGAAGGGGTTAT-3', WT R: 5'-GTGGGGTGTGCGGCTCAGGTAG-3', KO F: 5'-CAC GGCGAGCCTGTCAATCACGAG-3', KO R: 5'-TTGATG CCGTTCTTTTGCTTGTCG-3'; and for uc482 genotyping were For: 5'-GGAAATGAGGCCGAGTCAAG-3'; WT R: 5'-TACGAAGACATGTACCTGTGCG-3'; KO R: 5'-TGG ACTTGTCAGCTTCTTCCAA-3'. After weaning at age 21 days, mice were fed either a synthetic control diet (Dyets Inc., Bethlehem, PA, USA) containing 0.95\% calcium and $4.50 \mathrm{iU} / \mathrm{g}$ vitamin $\mathrm{D}_{3}$ or a synthetic low-calcium diet containing $0.001 \%$ calcium and $0.0 \mathrm{iU} / \mathrm{g}$ vitamin $\mathrm{D}_{3}$ (Dyets Inc.), as previously described (21). The low calcium/no vitamin $\mathrm{D}_{3}$ diet has previously been shown to unmask defects in the ability of the parathyroid glands to respond to deficiencies in dietary calcium, which may not be evident when calcium is abundant (21). Food and water were allowed ad libitum. Mice were killed and blood was collected from the jugular vein for plasma analysis using an AU400 clinical chemistry analyser (Olympus), and plasma calcium was corrected for albumin (Corr. Ca) using the formula: Corr. $\mathrm{Ca}=\mathrm{Ca}(\mathrm{mmol} / \mathrm{L})-$ $(($ Alb $(\mathrm{g} / \mathrm{L})-30) \times 0.017)$, as described previously (22)

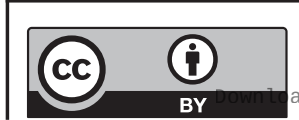

This work is licensed under a Creative Commons Attribution 4.0 International License. 
PTH concentrations were measured using an ELISA for mouse intact PTH (Immutopics, Quidel, San Diego, CA, USA), as described previously (22).

\section{Histological studies}

To study parathyroids of the knockout mice, the trachea, thyroid, and parathyroids were dissected en bloc and fixed for $24 \mathrm{~h}$ in $10 \%$ neutral buffered formalin. Paraffin sections ( $6 \mu \mathrm{m}$ thickness) were dewaxed and stained with haematoxylin and eosin (H\&E) using standard techniques. H\&E stained sections were viewed using an Eclipse E400 light microscope (Nikon) and images acquired using NISelements BR2.30 imaging software (Nikon). An estimation of parathyroid gland size was performed by measuring the largest cross-sectional area of the parathyroid gland in serial sections from each mouse, as described previously $(21,23)$, and corrected for body weight.

\section{Statistical analyses}

For human qRT-PCR analyses, data were analyzed using one-way ANOVA, and all data are represented as mean \pm S.D. fold change relative to unaffected males. For animal studies, data were analyzed using unpaired Student's $t$-test. All data are represented as mean \pm s.D., and for plasma biochemical results, significances are reported after Bonferroni correction for multiple comparisons.

\section{Results}

\section{Expression of SOX3, ATP11C and SNTG2 in patients with XLHPT}

PCR analysis using primers, previously described (8), that spanned the telomeric breakpoint, was used to confirm the presence or absence of the $\mathrm{X}$ chromosome deletioninsertion in three affected males, four carrier females, and three unaffected related males from the MO kindred (Fig. 2A). Thus, individuals II.5, II.6 and III.1, who are unaffected males with normocalcaemia, were confirmed to have only the wild-type (normal) allele; individuals IV.1, IV.2 and IV.3, who are affected males with hypocalcaemia due to XLHPT, were confirmed to have only the mutant allele; and individuals II.2, II.3, II.4 and III.2, who are carrier females with normocalcaemia, were confirmed to be heterozygous in having wild-type and mutant alleles (Fig. 2A). Parathyroid glands from XLHPT patients (7), and normal individuals were not available to

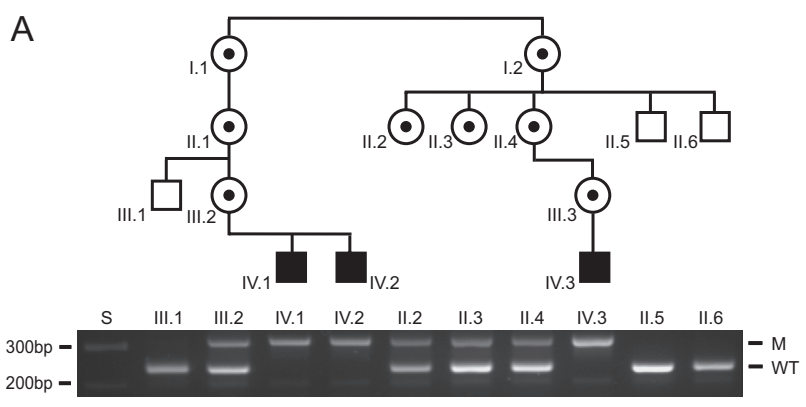

B
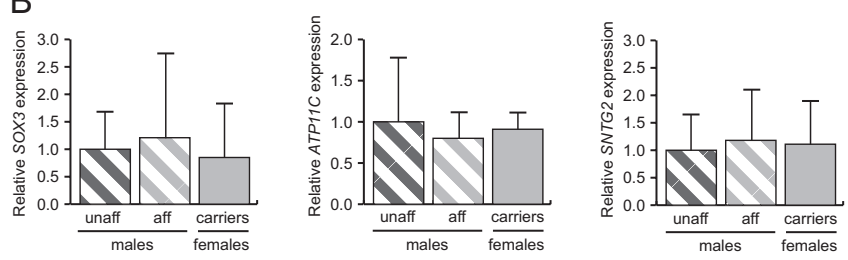

Figure 2

SOX3, SNTG2, and ATP11C expression in XLHPT family members. (A) Confirmation of the Xq27.1-2p25.3 deletion-insertion by PCR using primers spanning the telomeric breakpoint (Fig. 1) in four carrier females (circles with dots), and three affected males (filled squares) from the MO kindred. Three unaffected related males (open squares) in whom the Xq27.1-2p25.3 insert is not present are also shown. The PCR primers were designed to yield a wild-type (WT) product of $237 \mathrm{bp}$ in size, and a mutant (M) product of $321 \mathrm{bp}$ in size. $\mathrm{S}=$ size marker. (B) Quantitative reverse transcriptase (qRT)-PCR analyses of SOX3, ATP11C, and SNTG2 expression using mRNA obtained from EBV-lymphoblastoids from unaffected males (unaff) ( $n=3)$, affected males (aff) ( $n=3$ ) and carrier females (carriers) $(n=4)$, $(n=4$ replicates for each individual). Data are displayed as mean + s.D. relative to expression in unaffected males.

study the expression of SOX3 and ATP11C, which flank the interstitial deletion-insertion involving chromosomes Xq27.1 and 2p25.3, and the inserted region of SNTG2 in the XLHPT MO kindred (Fig. 1). Lymphoblastoid cell mRNA was therefore used to undertake qRT-PCR analysis of SOX3, ATP11C and SNTG2 expression (Fig. 2B). SOX3 expression (mean \pm s.D, ) was similar in affected males (1.21 \pm 1.53 -fold) and carrier females $(0.85 \pm 0.98$-fold), when compared to unaffected males $(1.00 \pm 0.68$-fold; $P>0.8$ ) (Fig. 2B). qRT-PCR analyses of ATP11C, which is located downstream of the deletion-insertion, and SNTG2, of which exons 2-16 are inserted from chromosome 2 p25.3, revealed no significant differences in expression of ATP11C or SNTG2 between affected males $(0.80 \pm 0.32$ fold and $1.18 \pm 0.92$-fold, respectively) or carrier females (0.91 \pm 0.20 -fold and 1.11 \pm 0.79 -fold, respectively), when compared to unaffected males $(1.00 \pm 0.78$-fold and $1.00 \pm 0.65$-fold; $P>0.8$ ) (Fig. 2B). These results indicated that specific spatiotemporal effects of the XLHPTassociated interstitial deletion-insertions on expression of SOX3 or other genes, ATP11C and SNTG2, postulated to occur in the developing parathyroids, were not occurring

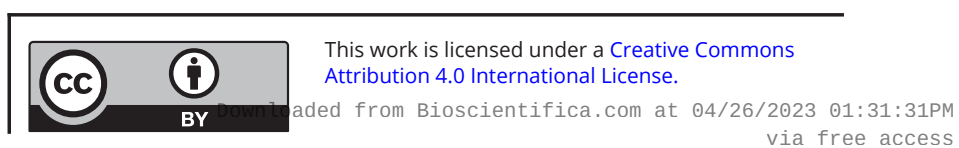


in lymphoblastoid cells, which are not representative of parathyroid cells. We therefore studied mouse knockout models deleted for Sox3 and uc482.

\section{Mice deleted for Sox3 have normal plasma calcium and PTH concentrations}

Mice were genotyped (Fig. 3A), and wild-type $\left(\operatorname{Sox} 3^{+/ Y}\right.$ ) and hemizygous $\left(\right.$ Sox $\left.^{-/ Y}\right)$ male adult mice, and wildtype $\left(\mathrm{Sox}^{+/+}\right)$and heterozygous $\left(\mathrm{Sox}^{+/-}\right)$female adult mice were found to have normal body weights and plasma biochemistry at ages 6 and 28 weeks (Table 1). Thus, corrected calcium concentrations in plasma were similar in: So $x 3^{+/ Y}$ mice compared to So $x 3^{-/ Y}$ mice $(3.08 \pm 0.11 \mathrm{mmol} / \mathrm{L}$ vs $3.05 \pm 0.15 \mathrm{mmol} / \mathrm{L}$ at 6 weeks, and $2.83 \pm 0.19 \mathrm{mmol} / \mathrm{L}$ vs $2.79 \pm 0.12 \mathrm{mmol} / \mathrm{L}$ at 28 weeks, $n=10-21)$; and in So $\times 3^{+/+}$mice compared to Sox $3^{+/-}$mice $(3.02 \pm 0.08 \mathrm{mmol} / \mathrm{L}$ vs $3.06 \pm 0.10 \mathrm{mmol} / \mathrm{L}$ at 6 weeks, and $2.65 \pm 0.12 \mathrm{mmol} / \mathrm{L}$ vs $2.73 \pm 0.11 \mathrm{mmol} / \mathrm{L}$ at 28 weeks, $n=9-25)$. Plasma PTH concentrations were also similar in: Sox $^{+/ \mathrm{Y}}$ and Sox $^{-/ \mathrm{Y}}$ mice $(11.8 \pm 7.6 \mathrm{pmol} / \mathrm{L}$ vs $12.8 \pm 10.4 \mathrm{pmol} / \mathrm{L}$ at 6 weeks, and $41.8 \pm 31.4 \mathrm{pmol} / \mathrm{L}$ vs
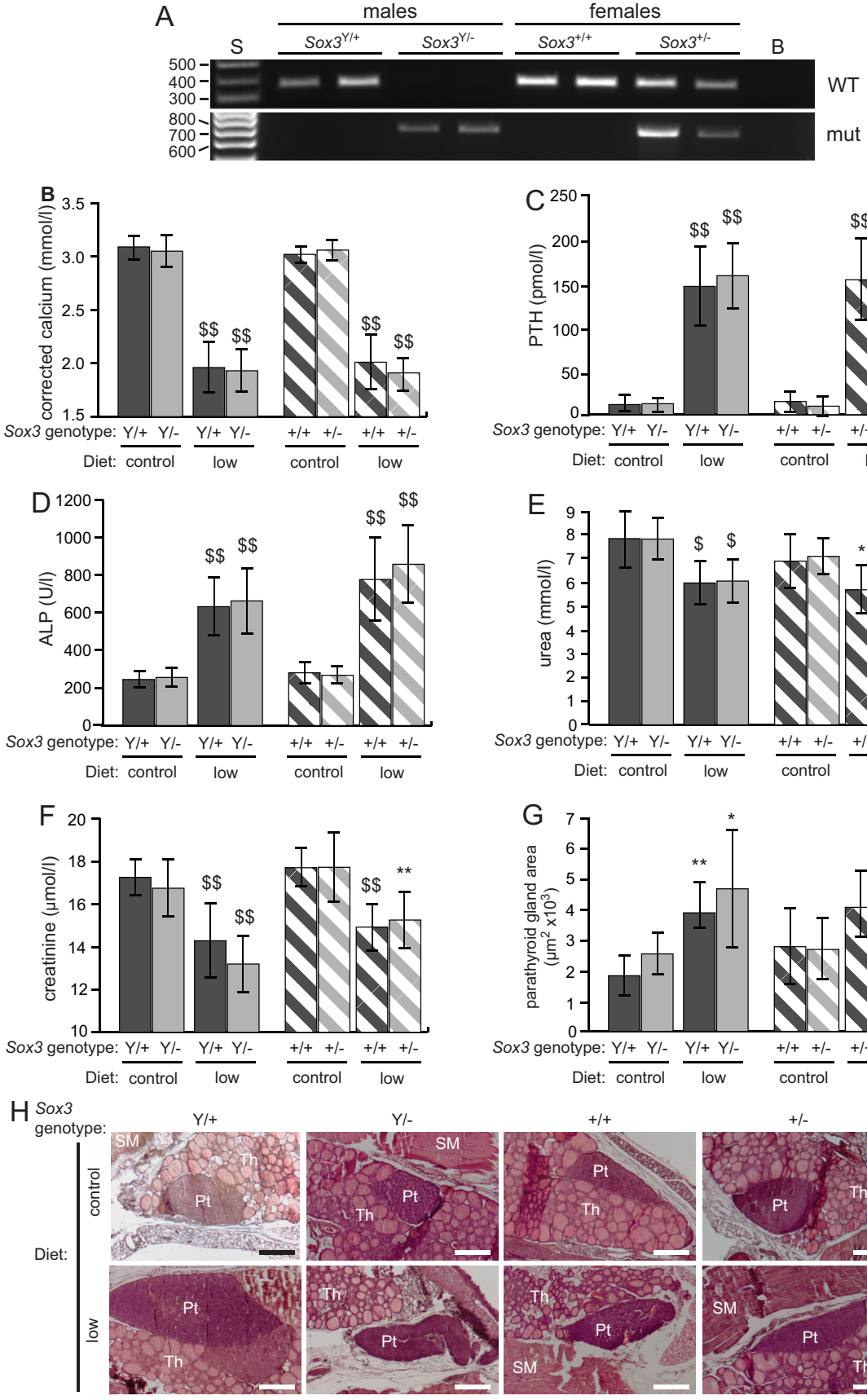

https://ec.bioscientifica.com https://doi.org/10.1530/EC-19-0478

2020 The authors Published by Bioscientifica Ltd

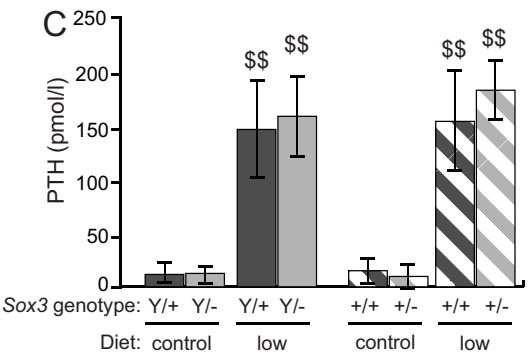

E
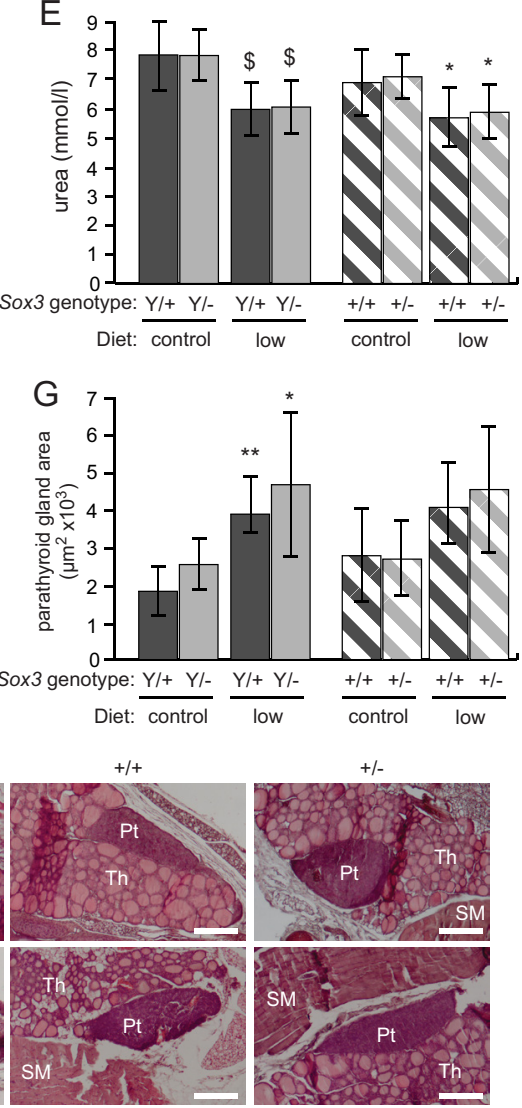

Figure 3

Plasma biochemistry and parathyroid gland sizes in wild-type and mutant Sox3 mice consuming either control or low calcium and vitamin D diets. (A) Genotyping of wild-type $\left(\mathrm{Sox}^{+/ N}\right)$ and hemizygous $\left(\mathrm{Sox}^{-/ Y}\right)$ male, and wild-type $\left(\mathrm{Sox}^{+/+}{ }^{+}\right)$ and heterozygous $\left(\mathrm{Sox}^{+/-}\right)$female mice. S: size marker; B: blank; WT: wild-type band; mut: mutant band. (B) Plasma corrected calcium; (C) plasma PTH; (D) plasma alkaline phosphatase (ALP) activity; (E) plasma urea; (F) plasma creatinine; $(G)$ parathyroid gland area. Wild-type males $(+/ Y)$ and mutant males $(-/ Y)$ are shown by the dark grey and light grey solid bars, respectively. Wild-type females $(+/+)$ and mutant carrier females (+/-) are shown by the dark grey and light grey hatched bars, respectively. Data are displayed as mean \pm S.D. $* P<0.05 ; * \star P<0.01$; ${ }^{\$} P<0.001 ;{ }^{\$} P<0.0001$ for mice on the low calcium and vitamin D (low $\mathrm{Ca}^{2+}$ and vit D) diet compared to mice of the same genotype on the normal diet. $(\mathrm{H})$ Representative histological images used for quantification of parathyroid gland area. Pt: parathyroid; Th: thyroid; SM: strap muscle. Scale bars $=200 \mu \mathrm{m}$ 
Table 1 Plasma biochemistry in 6- and 28-week-old wild-type and mutant Sox3 mice consuming the control diet.

\begin{tabular}{l}
\hline Genotype \\
\hline Age: 6 weeks \\
Body weight $(\mathrm{g})$ \\
Corr. Ca $(\mathrm{mmol} / \mathrm{L})$ \\
PTH $(\mathrm{pmol} / \mathrm{L})$ \\
Phosphate $(\mathrm{mmol} / \mathrm{L})$ \\
ALP $(\mathrm{U} / \mathrm{L})$ \\
Urea $(\mathrm{mmol} / \mathrm{L})$ \\
Creatinine $(\mu \mathrm{mol} / \mathrm{L})$ \\
Albumin $(\mathrm{g} / \mathrm{L})$ \\
Age: 28 weeks \\
Body weight $(\mathrm{g})$ \\
Corr. Ca $(\mathrm{mmol} / \mathrm{L})$ \\
PTH (pmol/L) \\
Phosphate $(\mathrm{mmol} / \mathrm{L})$ \\
ALP $(U / L)$ \\
Urea $(\mathrm{mmol} / \mathrm{L})$ \\
Creatinine $(\mu \mathrm{mol} / \mathrm{L})$ \\
Albumin $(\mathrm{g} / \mathrm{L})$ \\
\hline
\end{tabular}

\begin{tabular}{|c|c|}
\hline \multicolumn{2}{|c|}{ Males } \\
\hline $50 \times 3^{+/ Y}$ & $50 \times 3^{-/ Y}$ \\
\hline$(n=19-22)$ & $(n=14-18)$ \\
\hline $11.85 \pm 3.49$ & $11.74 \pm 3.70$ \\
\hline $3.08 \pm 0.11$ & $3.05 \pm 0.15$ \\
\hline $11.8 \pm 7.6$ & $12.8 \pm 10.4$ \\
\hline $4.24 \pm 0.76$ & $4.10 \pm 0.68$ \\
\hline $258.7 \pm 47.2$ & $270.2 \pm 49.4$ \\
\hline $7.85 \pm 1.24$ & $7.83 \pm 0.87$ \\
\hline $17.3 \pm 0.8$ & $16.8 \pm 1.3$ \\
\hline $30.5 \pm 1.7$ & $31.6 \pm 2.7$ \\
\hline$(n=10-14)$ & $(n=15-19)$ \\
\hline $47.51 \pm 6.81$ & $50.17 \pm 9.23$ \\
\hline $2.83 \pm 0.19$ & $2.79 \pm 0.12$ \\
\hline $41.8 \pm 31.4$ & $35.9 \pm 34.1$ \\
\hline $3.33 \pm 0.49$ & $3.26 \pm 0.54$ \\
\hline $81 \pm 15$ & $74 \pm 12$ \\
\hline $8.3 \pm 1.12$ & $8.2 \pm 0.82$ \\
\hline $15.9 \pm 0.9$ & $16.2 \pm 1.5$ \\
\hline $29.5 \pm 2.2$ & $30.7 \pm 0.8$ \\
\hline
\end{tabular}

\begin{tabular}{|c|c|}
\hline \multicolumn{2}{|c|}{ Females } \\
\hline So $3^{+/+}$ & Sox3 $3^{+/-}$ \\
\hline$(n=23-25)$ & $(n=12-15)$ \\
\hline $12.05 \pm 2.30$ & $12.12 \pm 2.71$ \\
\hline $3.02 \pm 0.08$ & $3.06 \pm 0.10$ \\
\hline $15.3 \pm 11.8$ & $9.9 \pm 10.6$ \\
\hline $4.07 \pm 0.62$ & $3.88 \pm 0.83$ \\
\hline $296.5 \pm 58.4$ & $282.4 \pm 48.4$ \\
\hline $6.90 \pm 1.13$ & $7.10 \pm 0.74$ \\
\hline $17.7 \pm 0.9$ & $17.7 \pm 1.6$ \\
\hline $31.7 \pm 2.0$ & $32.3 \pm 1.7$ \\
\hline$(n=8-12)$ & $(n=14-18)$ \\
\hline $32.16 \pm 1.66$ & $40.93 \pm 8.92$ \\
\hline $2.65 \pm 0.12$ & $2.73 \pm 0.11$ \\
\hline $35.6 \pm 23.8$ & $24.8 \pm 19.1$ \\
\hline $2.97 \pm 0.21$ & $3.06 \pm 0.64$ \\
\hline $98 \pm 24$ & $90 \pm 24$ \\
\hline $7.2 \pm 1.4$ & $8.1 \pm 1.2$ \\
\hline $16.1 \pm 1.7$ & $17.3 \pm 1.5$ \\
\hline $32.2 \pm 1.5$ & $31.9 \pm 1.9$ \\
\hline
\end{tabular}

Mean \pm S.D, values are shown. Wild-type males $\left(\right.$ So $\left.x 3^{+/}\right)$, mutant males $\left(\right.$So $\left.x 3^{-/}\right)$, wild-type females $\left(\right.$So $\left.\times 3^{+/+}\right)$, and mutant carrier females $\left(\right.$Sox $\left.3^{+/}\right)$. There were no significant differences between knockout and wild-type littermates at the same age.

ALP, alkaline phosphatase; Corr. Ca, corrected calcium; PTH, parathyroid hormone.

$35.9 \pm 34.1 \mathrm{pmol} / \mathrm{L}$ at 28 weeks, $n=14-22)$; and in $S o \times 3^{+/+}$ and $S o \times 3^{+/-}$mice $(15.3 \pm 11.8 \mathrm{pmol} / \mathrm{L}$ vs $9.9 \pm 10.6 \mathrm{pmol} / \mathrm{L}$ at 6 weeks, and $35.6 \pm 23.8 \mathrm{pmol} / \mathrm{L}$ vs $24.8 \pm 19.1 \mathrm{pmol} / \mathrm{L}$ at 28 weeks, $n=12-24$ ) (Table 1 ). In addition, the plasma phosphate, urea, creatinine and albumin concentrations, and alkaline phosphatase activity were similar in wild-type and mutant Sox3 mice at 6 and 28 weeks of age (Table 1).

The standard control mouse chow contains $0.95 \%$ calcium and $4.5 \mathrm{iU} / \mathrm{g}$ vitamin $\mathrm{D}_{3}$, which represent levels that are $\sim 150$-fold and $\sim 30$-fold higher, respectively, than those recommended for daily intake in humans (21). Furthermore, these high dietary contents of calcium and vitamin D have been reported to mask hypocalcaemia in mice with a different cause of HPT (21). We therefore challenged Sox $3^{+/ Y}$, Sox $3^{-/ Y}$, Sox $3^{+/+}$, and Sox $3^{+/-}$mice with a diet low in calcium $(0.001 \%)$ and lacking in vitamin $\mathrm{D}_{3}$ (low diet) from weaning until 60 days old. Wild-type male and female mice on the low diet had significantly lower plasma corrected calcium concentrations than those on the control diet (mean \pm s.D.) (low diet versus control diet for $S o x 3^{+/ Y}=1.96 \pm 0.24 \mathrm{mmol} / \mathrm{L}$ vs $3.08 \pm 0.11 \mathrm{mmol} / \mathrm{L}$, $P<0.001 ; \quad$ and $\quad \mathrm{Sox}^{+/+}=2.01 \pm 0.26 \mathrm{mmol} / \mathrm{L}$ vs $3.02 \pm 0.08 \mathrm{mmol} / \mathrm{L}, P<0.001, n=16-25)$ (Fig. 3B). These lower plasma corrected calcium concentrations, were not due to lower plasma albumin concentrations when on the low diets, as these plasma albumin concentrations were similar $\left(\right.$ Sox $^{+/+}=32.70 \pm 0.35 \mathrm{~g} / \mathrm{L}$, Sox $^{+/-}=32.58 \pm 0.24 \mathrm{~g} / \mathrm{L}$, $\operatorname{Sox}^{+/ \mathrm{Y}}=31.50 \pm 0.34 \mathrm{~g} / \mathrm{L}$ and $\operatorname{Sox}^{-/ \mathrm{Y}}=32.40 \pm 0.40 \mathrm{~g} / \mathrm{L}$ ), on low diet to those observed in mice on the control diet (Table 1). This hypocalcaemia was associated with significant increases in plasma PTH concentrations $\left(\right.$ Sox $3^{+/ Y}=150.1 \pm 46.3 \mathrm{pmol} / \mathrm{L}$ vs $11.8 \pm 7.6 \mathrm{pmol} / \mathrm{L}, P<0.001$; and $S o x 3^{+/+}=157.8 \pm 47.6 \mathrm{pmol} / 1$ vs $15.3 \pm 11.8 \mathrm{pmol} / \mathrm{L}$, $P<0.001, n=15-24)$ (Fig. 3C) and alkaline phosphatase (ALP) activities $\quad\left(\right.$ Sox $^{+/ \mathrm{Y}}=668.1 \pm 161.9 \quad \mathrm{U} / \mathrm{L} \quad$ vs $258.7 \pm 47.2 \mathrm{U} / \mathrm{L}, \quad P<0.001 ;$ So $\times 3^{+/+}=820.8 \pm 234.4 \mathrm{U} / \mathrm{L}$ vs $296.5 \pm 58.4 \mathrm{U} / \mathrm{L}, P<0.001, n=16-25)$ (Fig. $3 \mathrm{D}$ ). Wildtype mice on the low diet, compared to those on the control diet, also had significantly lower plasma urea concentrations $\left(\right.$ Sox $3^{+/ Y}=5.98 \pm 0.91 \mathrm{mmol} / \mathrm{L}$ vs $7.85 \pm 1.24$ $\mathrm{mmol} / \mathrm{L}, \quad P<0.001$; and $S o \times 3^{+/+}=5.69 \pm 0.99 \mathrm{mmol} / \mathrm{L}$ vs $6.90 \pm 1.13 \mathrm{mmol} / \mathrm{L}, P=0.042, n=18-25$ ) (Fig. 3E) and creatinine concentrations $\left(\right.$ Sox $^{+/ / \mathrm{Y}}=14.3 \pm 0.4 \mu \mathrm{mol} / \mathrm{L}$ vs $17.3 \pm 0.8 \mu \mathrm{mol} / \mathrm{L}, P<0.001$; and Sox $3^{+/+}=14.9 \pm 1.11 \mu \mathrm{mol} / \mathrm{L}$ vs $17.7 \pm 0.9 \mu \mathrm{mol} / \mathrm{L}, P<0.001, n=17-23$ ) (Fig. $3 \mathrm{~F}$ ).

Similar to wild-type mice, mutant male $\left(\mathrm{Sox}^{-/ \mathrm{Y}}\right)$ and heterozygote female $\left(\mathrm{Sox3}^{+-}{ }^{+-}\right)$mice on the low diet also had significantly lower plasma corrected calcium concentrations than those on the control diet $\left(\right.$ Sox $^{-/ Y}=1.93 \pm 0.20 \mathrm{mmol} / \mathrm{L}$ vs $3.05 \pm 0.15 \mathrm{mmol} / \mathrm{L}$, $P<0.001 ; \quad$ and Sox $^{+/-}=1.91 \pm 0.14 \quad \mathrm{mmol} / \mathrm{L}$ vs $3.06 \pm 0.10 \mathrm{mmol} / \mathrm{L}, P<0.001, n=13-24)$ (Fig. 3B). This was associated with significantly higher plasma: PTH concentrations $\left(\right.$ Sox $3^{-/ Y}=162.6 \pm 37.6 \mathrm{pmol} / \mathrm{L}$ vs $12.8 \pm 10.4$ $\mathrm{pmol} / \mathrm{L}, \quad P<0.001$; and Sox $^{+/-}=187.5 \pm 28.6 \mathrm{pmol} / \mathrm{L}$ vs $9.9 \pm 10.6 \mathrm{pmol} / \mathrm{L}, P<0.001, n=13-21$ ) (Fig. 3C); and ALP 
activities $\left(\right.$ Sox3 $^{-/ Y}=700.3 \pm 183.2 \mathrm{U} / \mathrm{L}$ vs $270.2 \pm 49.4 \mathrm{U} / \mathrm{L}$, $P<0.001 ;$ Sox $3^{+/}=906.4 \pm 217.2 \mathrm{U} / \mathrm{L}$ vs $282.4 \pm 48.4 \mathrm{U} / \mathrm{L}$, $P<0.001, n=12-22$ ) (Fig. 3D). So $\times 3^{-/ Y}$ and Sox $3^{+/-}$mice on the low diet also had significantly lower plasma: urea concentrations $\left(\right.$ So $3^{-/ Y}=6.06 \pm 0.92 \mathrm{mmol} / \mathrm{L}$ vs $\quad 7.83 \pm 0.87 \quad \mathrm{mmol} / \mathrm{L}, \quad P<0.001 ; \quad$ and So $\times 3^{+/-}=5.88 \pm 0.92 \mathrm{mmol} / \mathrm{L}$ vs $7.10 \pm 0.74 \mathrm{mmol} / \mathrm{L}$, $P<0.018, n=13-25)$ (Fig. 3E); and creatinine concentrations $\left(\right.$ Sox $^{-/ \mathrm{Y}}=13.2 \pm 1.3 \mu \mathrm{mol} / \mathrm{L}$ vs $16.8 \pm 1.4 \mu \mathrm{mol} / \mathrm{L}, P<0.001$; and Sox $^{+/-}=15.3 \pm 1.3 \mu \mathrm{mol} / \mathrm{L}$ vs $17.7 \pm 1.6 \mu \mathrm{mol} / \mathrm{L}$, $P<0.002, n=12-23$ ) (Fig. 3F). The plasma corrected calcium and PTH concentrations in $S o \times 3^{-/ Y}$ and So $\times 3^{+/-}$ mice on the low diet were not statistically different to the wild-type mice on the low diet, indicating that Sox $3^{-/ Y}$ and $\mathrm{Sox}^{3^{+/-}}$mice have normal parathyroid function (Fig. 3B and C). Plasma ALP activities and urea and creatinine concentrations were also similar in wild-type mice compared to $\operatorname{Sox}^{-/ Y}$ and Sox $3^{+/-}$mice on the low calcium diet (Fig. 3D, E and F).

Histological analysis of parathyroid gland size from wild-type and mutant Sox3 mice revealed that parathyroid gland areas in $S_{0 \times 3}{ }^{+/ Y}$ and $S o x 3^{-/ Y}$ mice were significantly greater, in keeping with diet-induced secondary hyperparathyroidism, in mice on the low diet, when compared to the control diet $\left(\right.$ Sox $^{+/ / Y}=3885 \pm 1012 \mu \mathrm{m}^{2} / \mathrm{g}$ vs $1824 \pm 656 \mathrm{\mu m}^{2} / \mathrm{g}, P=0.007$; and $S_{0 \times 3}{ }^{-/ \mathrm{Y}}=4672 \pm 1914$ $\mu^{2} / \mathrm{g}$ vs $\left.2539 \pm 684 \mu \mathrm{m}^{2} / \mathrm{g}, P=0.040, n=4\right)$; however, there was no difference between $S o x 3^{+/ Y}$ and Sox $3^{-/ Y}$ mice on each diet (normal diet $P=0.091$; low $\operatorname{diet} P=0.247$ ) (Fig. $3 \mathrm{G}$ and H). Parathyroid gland sizes in $S_{0 \times 3} 3^{+/+}$and Sox $3^{+/-}$ mice were similar on the low diet compared to the control diet $\left(\right.$ Sox $3^{+/+}=4065 \pm 1178 \mu \mathrm{m}^{2} / \mathrm{g}$ vs $2775 \pm 1244 \mu \mathrm{m}^{2} / \mathrm{g}$, $P=0.091 ; \quad$ and $\quad$ So $\times 3^{+/-}=4542 \pm 1664 \quad \mathrm{\mu m}^{2} / \mathrm{g} \quad$ vs $\left.2684 \pm 1010 \mu \mathrm{m}^{2} / \mathrm{g}, P=0.052, n=4\right)$, and there was no difference between $\mathrm{Sox}^{+/+}$and Sox3 ${ }^{+/-}$mice on each diet (normal diet $P=0.457$; low $\operatorname{diet} P=0.328$ ) (Fig. 3G). Thus, So $\times 3^{-/ Y}$ and Sox $3^{+/-}$mice appear to have normal parathyroid function and normal responses to hypocalcaemia, and loss of Sox 3 does not result in smaller parathyroids or HPT.

\section{Mice deleted for ultraconserved element uc482 have normal plasma calcium and PTH concentrations}

Mice were genotyped (Fig. 4A) and wild-type (uc482 $\left.2^{+/ Y}\right)$ and hemizygous $\left(u c 482^{-/ Y}\right)$ male adult mice, and wildtype $\left(u c 482^{+/+}\right)$and heterozygous $\left(u c 482^{+/-}\right)$female adult mice were found to have normal plasma biochemistry at the ages of 8 weeks and 28 weeks (Table 2). Thus, plasma corrected calcium concentrations were similar in $u c 482^{+/ Y}$ mice compared to $u c 482^{-/ Y}$ mice $(2.95 \pm 0.08 \mathrm{mmol} / \mathrm{L}$ vs $2.98 \pm 0.10 \mathrm{mmol} / \mathrm{L}$ at 8 weeks, and $2.76 \pm 0.08 \mathrm{mmol} / \mathrm{L}$ vs $2.83 \pm 0.13 \mathrm{mmol} / \mathrm{L}$ at 28 weeks, $n=10-24)$; and in $u c 482^{+/+}$mice compared to $u c 482^{+/-}$mice $(2.80 \pm 0.07 \mathrm{mmol} / \mathrm{L}$ vs $2.84 \pm 0.12 \mathrm{mmol} / \mathrm{L}$ at 8 weeks, and $2.70 \pm 0.05 \mathrm{mmol} / \mathrm{L}$ vs $2.72 \pm 0.12 \mathrm{mmol} / \mathrm{L}$ at 28 weeks, $n=7-42$ ) (Table 2). Plasma PTH concentrations were also similar in $u c 482^{+/ Y}$ and $u c 482^{-/ Y}$ mice $(12.9 \pm 9.3 \mathrm{pmol} / \mathrm{L}$ vs $12.1 \pm 9.0 \mathrm{pmol} / \mathrm{L}$ at 8 weeks, and $19.9 \pm 16.7 \mathrm{pmol} / \mathrm{L}$ vs $26.7 \pm 15.3 \mathrm{pmol} / \mathrm{l}$ at 28 weeks, $n=14-20$ ); and in $u c 482^{+/+}$ and $u c 482^{+/-}$mice $(11.1 \pm 10.4 \mathrm{pmol} / \mathrm{L}$ vs $23.5 \pm 24.3 \mathrm{pmol} / \mathrm{L}$ at 8 weeks, and $18.4 \pm 20.2 \mathrm{pmol} / \mathrm{L}$ vs $13.6 \pm 12.0 \mathrm{pmol} / \mathrm{L}$ at 28 weeks, $n=9-19$ ) (Table 2 ). In addition, the plasma phosphate, urea, creatinine and albumin concentrations, and alkaline phosphatase activities were similar in wildtype and mutant $u c 482$ mice at 8 weeks and 28 weeks of age (Table 2).

When challenged with the low diet for 60 days, plasma corrected calcium concentrations were significantly lower in: male wild-type $\left(u c 482^{+/ Y}\right)$ and mutant hemizygous $\left(u c 482^{-/ Y}\right)$ mice $\quad\left(u c 482^{+/ Y}=2.01 \pm 0.17 \quad \mathrm{mmol} / \mathrm{L}\right.$ vs $2.95 \pm 0.08 \mathrm{mmol} / \mathrm{L}, P<0.0001$; and $u c 482^{-/ Y}=1.90 \pm 0.27$ vs $2.98 \pm 0.10 \mathrm{mmol} / \mathrm{L}, \quad P<0.0001, n=10-24) ;$ and in female wild-type $\left(u c 482^{+/+}\right)$and heterozygous $\left(u c 482^{+/-}\right)$ mice $\quad\left(u c 482^{+/+}=1.92 \pm 0.11 \mathrm{mmol} / \mathrm{L}\right.$ vs $2.80 \pm 0.07$ $\mathrm{mmol} / \mathrm{L}, P<0.0001$; and $u c 482^{+/-}=1.93 \pm 0.17 \mathrm{mmol} / \mathrm{L}$ vs $2.84 \pm 0.12 \mathrm{mmol} / \mathrm{L}, P<0.0001, n=14-42$ ) (Fig. 4B). These lower plasma corrected calcium concentrations were not due to lower plasma albumin concentrations when on the low diets, as these plasma albumin concentrations were similar $\left(\right.$ uc $42^{+/+}=30.44 \pm 0.34 \mathrm{~g} / \mathrm{L}, \quad$ uc $482^{+/=}=30.73 \pm 0.26 \mathrm{~g} / \mathrm{L}$, $\mathrm{uc} 482^{+/ \mathrm{Y}}=30.63 \pm 0.38 \mathrm{~g} / \mathrm{L}$ and $\mathrm{uc} 482^{-/ \mathrm{Y}}=30.41 \pm 0.70 \mathrm{~g} / \mathrm{L}$ ), on low diet to those observed in mice on the control diet (Table 2). This was associated with significantly higher plasma PTH concentrations in $u c 482^{+/ Y}$ and $u c 482^{-/ Y}$ mice $\left(u c 482^{+/ Y}=194.6 \pm 48.2 \mathrm{pmol} / \mathrm{L}\right.$ vs $12.9 \pm 9.3 \mathrm{pmol} / \mathrm{L}$, $P<0.0001 ;$ and $u c 482^{-/ Y}=194.0 \pm 36.3 \mathrm{pmol} / \mathrm{L} \quad \mathrm{vs}$ $12.1 \pm 9.0 \mathrm{pmol} / \mathrm{L}, P<0.0001, n=10-20)$; and in $u c 482^{+/+}$ and $u c 482^{+/-}$mice $\left(u c 482^{+/+}=211.3 \pm 26.4 \mathrm{pmol} / \mathrm{L}\right.$ vs $11.1 \pm 10.4 \mathrm{pmol} / \mathrm{L}, \quad P<0.0 .0001 ; \quad$ and $u c 482^{+/-}=$ $226.3 \pm 54.4 \mathrm{pmol} / \mathrm{L}$ vs $23.5 \pm 24.3 \mathrm{pmol} / \mathrm{L}, P<0.0001$, $n=9-19)$ (Fig. 4C). Plasma ALP activities were also significantly higher in: $u c 482^{+/ Y}$ and $u c 482^{-/ Y}$ mice $\left(u c 482^{+/ Y}=1062.7 \pm 233.1 \quad \mathrm{U} / \mathrm{L} \quad\right.$ vs $280.7 \pm 53.9 \quad \mathrm{U} / \mathrm{L}$, $P<0.0001 ; \quad$ and $\quad u c 482^{-/ Y}=1123.0 \pm 125.4 \quad \mathrm{U} / \mathrm{L} \quad$ vs $279.8 \pm 36.8 \mathrm{U} / \mathrm{L}, P<0.0001, n=17-29)$; and in $u c 482^{+/+}$ and $u c 482^{+/-}$mice $\left(u c 482^{+/+}=1189.9 \pm 211.0 \mathrm{U} / \mathrm{L}\right.$ vs $286.8 \pm 41.1 \mathrm{U} / \mathrm{L}, P<0.0001$; and $u c 482^{+/-}=1133.7 \pm 346.5$ $\mathrm{U} / \mathrm{L}$ vs $293.8 \pm 40.1 \mathrm{U} / \mathrm{L}, P<0.0001, n=13-40$ ) (Fig. $4 \mathrm{D}$ ). The plasma corrected calcium and PTH concentrations,

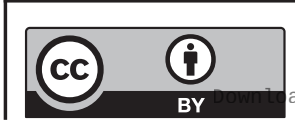

This work is licensed under a Creative Commons Attribution 4.0 International License. ed from Bioscientifica.com at 04/26/2023 01:31:31PM 
A
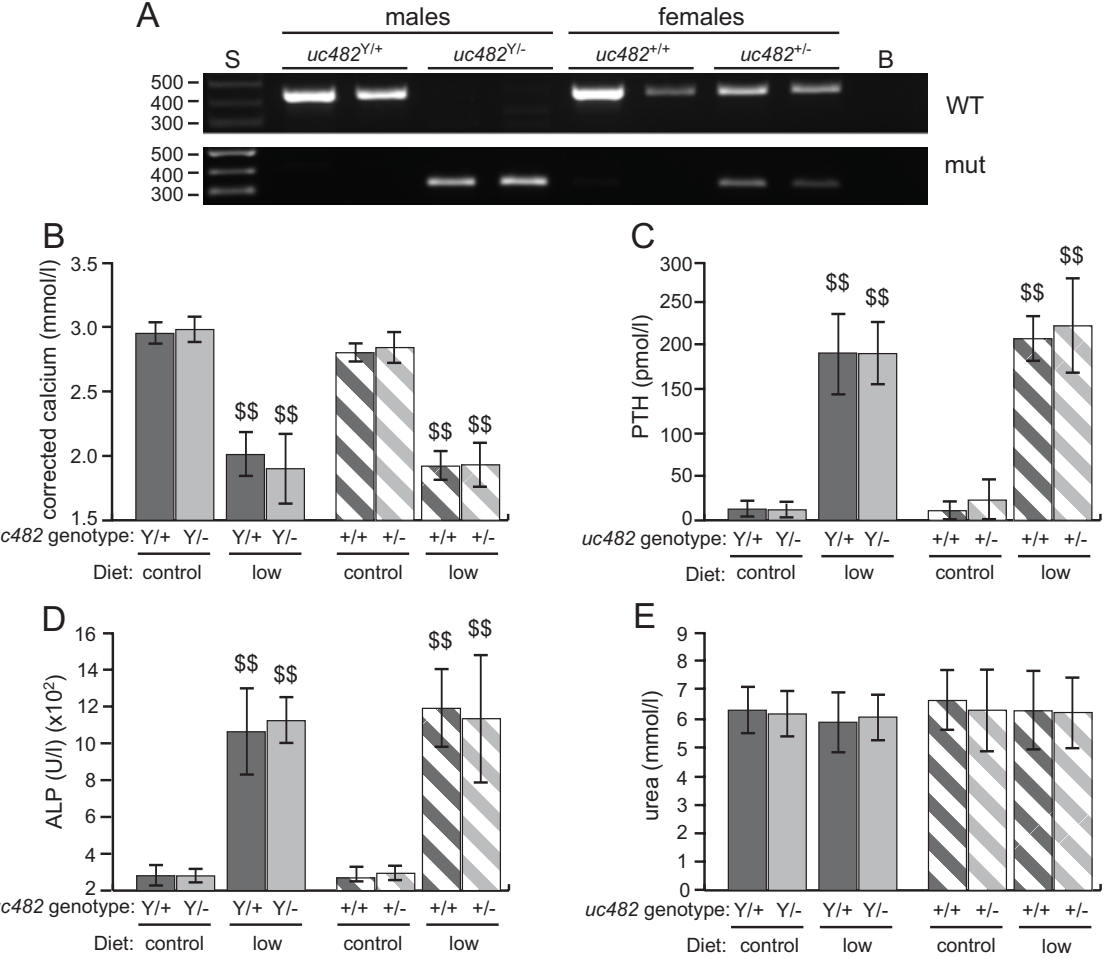

E
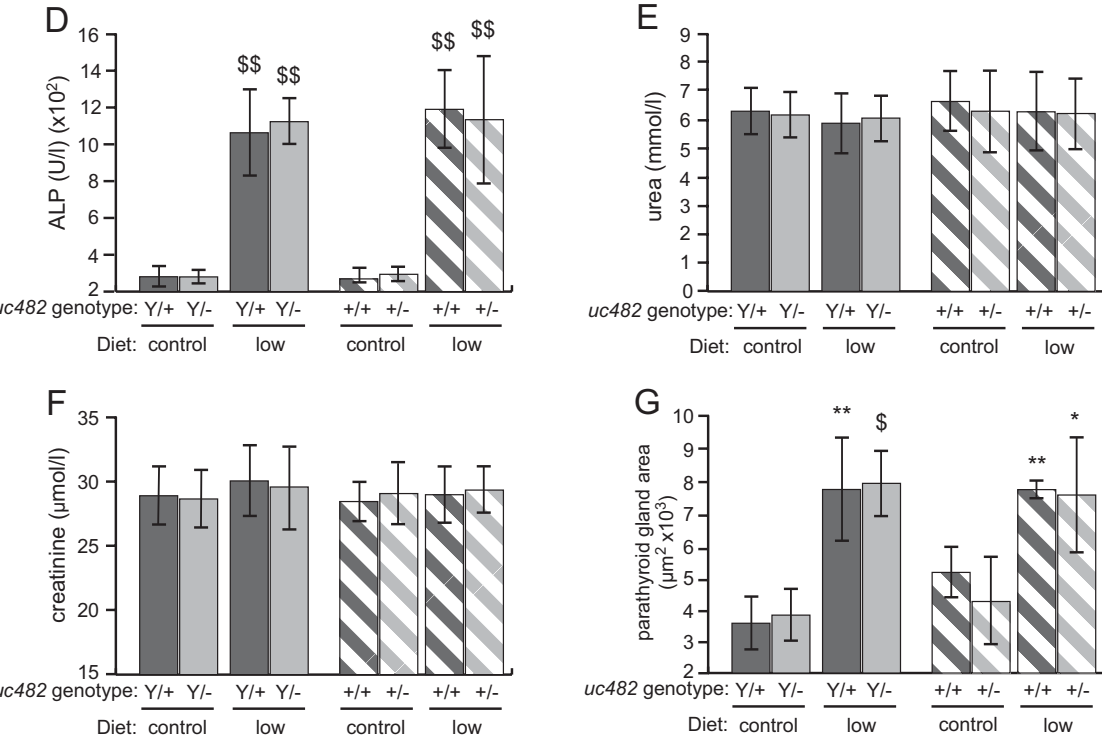

Figure 4

Plasma biochemistry and parathyroid gland sizes in wild-type and mutant $u c 482$ mice consuming either control or low calcium and vitamin $D$ diets. (A) Genotyping of wild-type $\left(u c 482^{+\wedge}\right)$ and hemizygous (uc482- $2^{-N}$ ) male, and wild-type $\left(u c 482^{+/+}\right)$and heterozygous (uc482 ${ }^{+/-}$) female mice. S: size marker; B: blank; WT: wild-type band; mut: mutant band. (B) Plasma corrected calcium; (C) plasma PTH; (D) plasma alkaline phosphatase (ALP) activity; (E) plasma urea; (F) plasma creatinine; $(G)$ parathyroid gland area. Wild-type males $(+/ Y)$ and mutant males $(-/ Y)$ are shown by the dark grey and light grey solid bars, respectively. Wild-type females (+/+) and mutant carrier females (+/-) are shown by the dark grey and light grey hatched bars, respectively. Data are presented as mean \pm S.D. $* P<0.05 ; * \star P<0.01$; ${ }^{\$} P<0.001 ;{ }^{\$} P<0.0001$ for mice on the low calcium and vitamin $\mathrm{D}$ (low $\mathrm{Ca}^{2+}$ and vit $\mathrm{D}$ ) diet compared to mice of the same genotype on the normal diet. $(\mathrm{H})$ Representative histological images used for quantification of parathyroid gland area. Pt: parathyroid; Th: thyroid; SM: strap muscle. Scale bars $=200 \mu \mathrm{m}$.

and plasma ALP activities in $u c 482^{-/ Y}$ and $u c 482^{+/-}$mice on the low diet were similar to those of the $u c 482^{+/ Y}$ and $u c 482^{+/+}$mice, respectively, on the control diet, indicating that $u c 482^{-/ Y}$ and $u c 482^{+/-}$mice have normal parathyroid function (Fig. 4B, C and D). There were no differences in plasma urea or creatinine concentrations between $u c 482^{+/ Y}, u c 482^{+/+}, u c 482^{-/ Y}$ or $u c 482^{+/-}$mice on the low diet compared to the control diet (Fig. 4E and F).

Histological analysis of parathyroid gland size from wild-type and mutant uc482 mice revealed that parathyroid gland areas in all genotypes were significantly larger, in keeping with diet-induced secondary hyperparathyroidism, in mice on the low diet compared to the control diet $\left(u c 482^{+/ Y}=7697 \pm 1596 \mu \mathrm{m}^{2} / \mathrm{g}\right.$ vs $3545 \pm 824 \mathrm{\mu m}^{2} / \mathrm{g}, P=0.002 ; u c 482^{-/ \mathrm{Y}}=7887 \pm 1016 \mathrm{\mu m}^{2} / \mathrm{g}$ vs $3797 \pm 802 \mu \mathrm{m}^{2} / \mathrm{g}, P<0.001 ; u c 482^{+/+}=7525 \pm 1780 \mu \mathrm{m}^{2} / \mathrm{g}$ vs $\quad 4220 \pm 1348 \quad \mathrm{um}^{2} / \mathrm{g}, \quad P=0.013 ;$ and $u c 482^{+/-}=$ $7693 \pm 276 \mu^{2} / g$ vs $5123 \pm 782 \mu \mathrm{m}^{2} / \mathrm{g}, \quad P=0.004$, $n=4$ ) (Fig. 4G, H). There were no differences between $u c 482^{+/ Y}$ and $u c 482^{-/ Y}$ mice, or between $u c 482^{+/+}$and 
Table 2 Plasma biochemistry in 8 and 28 week old wild-type and mutant uc482 mice consuming the control diet.

\begin{tabular}{l}
\hline Genotype \\
\hline Age: 8 weeks \\
Body weight $(\mathrm{g})$ \\
Corr. Ca $(\mathrm{mmol} / \mathrm{L})$ \\
PTH $(\mathrm{pmol} / \mathrm{L})$ \\
Phosphate $(\mathrm{mmol} / \mathrm{L})$ \\
ALP $(\mathrm{U} / \mathrm{L})$ \\
Urea $(\mathrm{mmol} / \mathrm{L})$ \\
Creatinine $(\mu \mathrm{mol} / \mathrm{L})$ \\
Albumin $(\mathrm{g} / \mathrm{L})$ \\
Age: 28 weeks \\
Body weight $(\mathrm{g})$ \\
Corr. Ca $(\mathrm{mmol} / \mathrm{L})$ \\
PTH $(\mathrm{pmol} / \mathrm{L})$ \\
Phosphate $(\mathrm{mmol} / \mathrm{L})$ \\
ALP $(\mathrm{U} / \mathrm{L})$ \\
Urea $(\mathrm{mmol} / \mathrm{L})$ \\
Creatinine $(\mu \mathrm{mol} / \mathrm{L})$ \\
Albumin $(\mathrm{g} / \mathrm{L})$ \\
\hline
\end{tabular}

\begin{tabular}{cc}
\hline & Mal \\
\hline$u c 482^{+N}$ & $(n=17-25)$ \\
$21.32 \pm 2.53$ \\
$2.95 \pm 0.08$ \\
$12.9 \pm 9.3$ \\
$4.10 \pm 0.70$ \\
$280.7 \pm 53.9$ \\
$6.29 \pm 0.80$ \\
$28.88 \pm 2.23$ \\
$29.8 \pm 1.5$ \\
$(n=8-14)$ \\
$37.13 \pm 4.94$ \\
$2.76 \pm 0.08$ \\
$19.9 \pm 16.7$ \\
$3.55 \pm 0.55$ \\
$69.7 \pm 7.5$ \\
$10.04 \pm 1.04$ \\
$33.8 \pm 2.2$ \\
$30.5 \pm 1.3$
\end{tabular}

\begin{tabular}{cc}
\hline & Fema \\
\hline$u c 482^{+++}$ \\
\hline$(n=9-15)$ \\
$17.51 \pm 1.25$ \\
$2.80 \pm 0.07$ \\
$11.1 \pm 10.4$ \\
$4.01 \pm 0.54$ \\
$286.8 \pm 41.1$ \\
$6.63 \pm 1.04$ \\
$28.43 \pm 1.55$ \\
$32.0 \pm 1.9$ \\
$(n=11-15)$ \\
$27.07 \pm 4.93$ \\
$2.70 \pm 0.05$ \\
$18.4 \pm 20.2$ \\
$3.20 \pm 0.54$ \\
$79.7 \pm 8.5$ \\
$8.46 \pm 0.83$ \\
$33.4 \pm 1.7$ \\
$31.5 \pm 1.8$
\end{tabular}

emales

$u(482-1 \times$

$(n=20-25)$

$21.62 \pm 1.49$

$2.98 \pm 0.10$

$12.1 \pm 9.0$

$4.17 \pm 0.39$

$279.8 \pm 36.8$

$6.16 \pm 0.79$

$28.63 \pm 2.20$

$29.0 \pm 1.3$

( $n=10-16)$

$37.79 \pm 5.28$

$2.83 \pm 0.13$

$26.7 \pm 15.3$

$3.71 \pm 0.66$

$71.0 \pm 7.0$

$9.23 \pm 1.21$

$35.3 \pm 2.2$

$31.1 \pm 1.3$

\begin{tabular}{c}
$u c 482^{+/}-$ \\
\hline$(n=19-44)$ \\
$17.20 \pm 1.51$ \\
$2.84 \pm 0.12$ \\
$23.5 \pm 24.3$ \\
$3.95 \pm 0.52$ \\
$293.8 \pm 40.1$ \\
$6.29 \pm 1.42$ \\
$29.05 \pm 2.38$ \\
$31.7 \pm 1.5$ \\
$(n=8-12)$ \\
$26.14 \pm 4.28$ \\
$2.72 \pm 0.12$ \\
$13.6 \pm 12.0$ \\
$3.42 \pm 0.51$ \\
$85.3 \pm 18.8$ \\
$8.73 \pm 1.18$ \\
$34.3 \pm 3.0$ \\
$31.8 \pm 1.6$
\end{tabular}

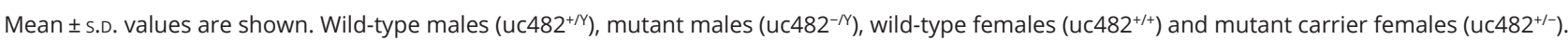
There were no significant differences between knock-out and wild-type littermates at the same age.

ALP, alkaline phosphatase; Corr. Ca, corrected calcium; PTH, parathyroid hormone.

$u c 482^{+/-}$mice, either on the control diet, or the low diet $\left(u c 482^{+/ Y}\right.$ vs $u c 482^{-/ Y}$ control diet $P=0.338$ and low diet $P=0.424$; and $u c 482^{+/+}$vs $u c 482^{+/-}$control diet $P=0.145$ and low diet $P=0.432$ ). Thus, $u c 482^{-/ Y}$ and $u c 482^{+/-}$mice appear to have normal parathyroid gland function and normal responses to hypocalcaemia, and loss of uc482 does not result in smaller parathyroids or HPT.

\section{Discussion}

The molecular and cellular effects of the interstitial deletion-insertion involving chromosomes Xq27.1 and 2p25.3 in two families with XLHPT and their effects on SOX3 expression in the etiology of HPT remain to be elucidated (Fig. 1). Elucidation of the mechanism(s) may also have relevance to other disorders, as interstitial deletion-insertions involving deletions at the same locus on Xq27.1, but insertions from other autosomes, have been described in other diseases $(7,24,25,26)$ (Fig. 5). For example, three families with X-linked congenital generalized hypertrichosis $(\mathrm{CGH})$ have been reported to have deletion-insertions comprising: a Chinese family with a $\sim 1.3 \mathrm{~kb}$ Xq27.1 deletion and a $\sim 125.5 \mathrm{~kb} 5$ q35.3 insertion containing intronic sequence from within collagen type 23, alpha 1 (COL23A1); a Mexican family with a $7 \mathrm{bp}$ deletion and a $\sim 300 \mathrm{~kb} 4 \mathrm{q} 31.22-31.23$ inverted insertion containing protein arginine methyltransferase 10 (PRMT10), transmembrane protein 184C (TMEM184C), and parts of Rho GTPase activating protein 10 (ARHGAP10) and endothelin receptor type A (EDNRA); and another Mexican family with a 2 bp Xq27.1 deletion and a $\sim 389 \mathrm{~kb} 6$ p21.2 insertion containing Dishevelled-associated activator of morphogenesis 2 (DAAM2) and kinesin family member 6 (KIF6) and a 56 bp 3q21.1 insertion containing part of family with sequence similarity 162 member A $(F A M 162 A)(27,28,29)$ (Fig. 5). There are two distinguishing clinical features in these CGH families. In the Chinese family, the presence of spina bifida in the proband and scoliosis in 4 family members implicates a role for SOX3, which has been linked to neural tube defects in man $(24,25)$, chicken (26), Drosophila (30) and zebrafish (31). In the Mexican family with the 6p21.2 and 3q21.1 insertions, several members also had dental anomalies. The disease mechanism in this family was postulated to be a position effect on fibroblast growth factor 13 (FGF13), located $\sim 1.2 \mathrm{Mb}$ proximal to the insertion site, and decreased expression of FGF13, which is found in developing hair follicles, dental mesenchyme and in developing tooth buds, was detected in patient keratinocytes (27). By contrast, a patient with $\mathrm{XX}$ male sex reversal was found to have a $4 \mathrm{bp}$ deletion at the same locus on Xq27.1 and a $~ 774 \mathrm{~kb} 1 \mathrm{q} 25.2-25.3$ insertion containing 6 complete genes (acyl-CoA binding domain containing 6 (ACBD6), xenotropic and polytropic retrovirus receptor 1 (XPR1), unknown gene KIAA1614, https://ec.bioscientifica.com

https://doi.org/10.1530/EC-19-0478 (c) 2020 The authors Published by Bioscientifica Ltd

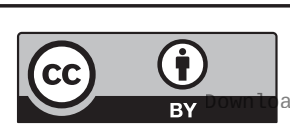

This work is licensed under a Creative Commons Attribution 4.0 International License. ded from Bioscientifica.com at 04/26/2023 01:31:31PM via free access 


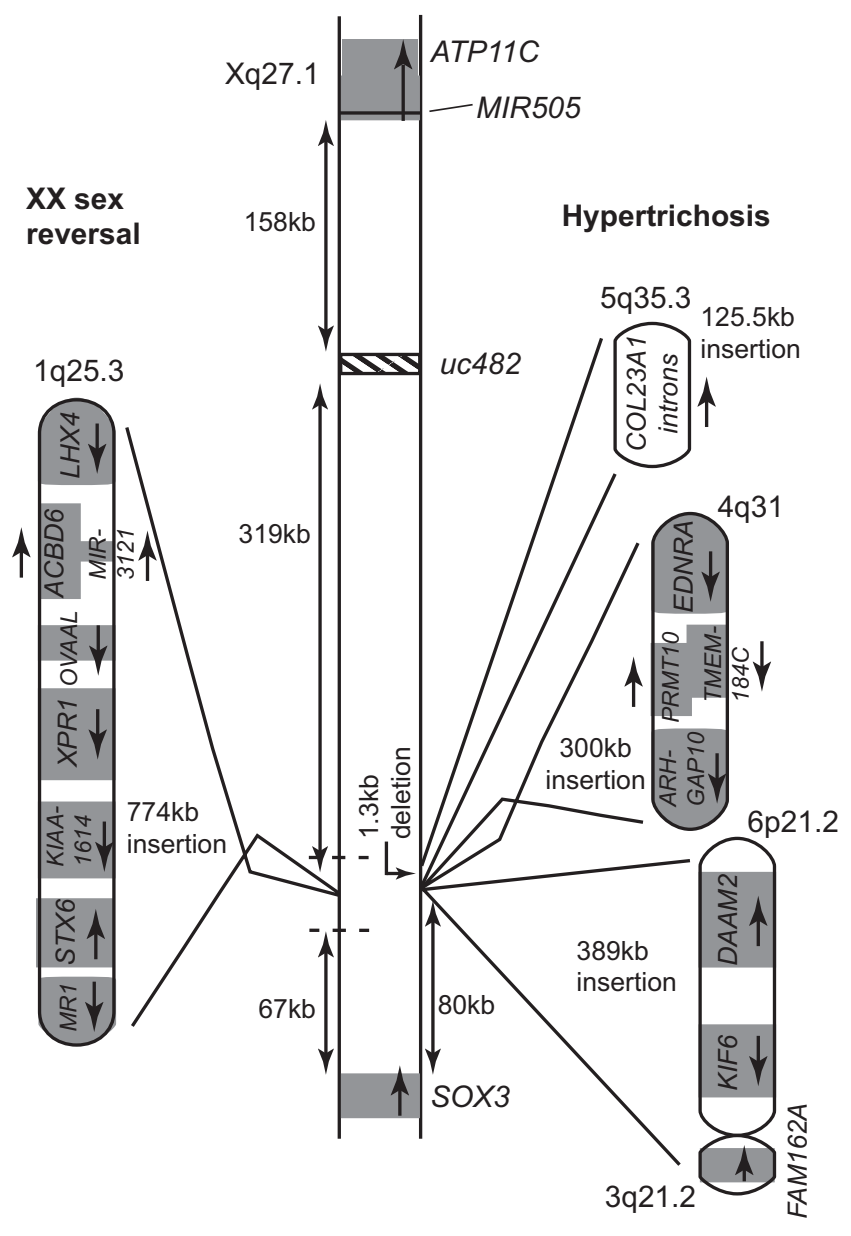

Figure 5

Chromosomal rearrangements associated with XX sex reversal and hypertrichosis. A patient with XX sex reversal was found to have an interstitial deletion-insertion involving chromosome Xq27.1 and chromosome 1q25.3 (11). One family from China and two unrelated families from Mexico with hypertrichosis have been reported to have interstitial deletion-insertions involving chromosome Xq27.1 and chromosomes 5q35.3, 4q31, and 6p21.2, respectively $(23,24,25)$. Dotted lines denote the location of the XLHPT interstitial deletion-insertions.

syntaxin 6 (STX6), ovarian adenocarcinoma amplified long ncRNA (OVAAL), and microRNA 3121 (MIR3121)) and two partial genes (LIM homeobox 4 (LHX4) and major histocompatibility complex, class-I related (MR1)), that switched on SOX3 expression in lymphoblastoid cells from the patient but did not affect FGF13 expression (12) (Fig. 5). Combined, these studies demonstrate that diverse phenotypes can result from similar sized insertions into the same Xq27.1 locus, and that similar phenotypes (e.g. CGH) can result from insertions from different autosomes, highlighting the complexity underlying longrange gene regulation and the effects of chromosomal rearrangements in disease. Indeed, Hi-C chromatin interaction analyses have revealed that the alterations of genomic repressors or enhancers can affect long-range gene expression, and thus it is feasible that these deletioninsertions of Xq27.1 may affect genes that are nearby SOX3, but which exert their effects on different distant genes. For example, MIR505 located downstream of SOX3 (Figs 1 and 5) encodes a microRNA that inhibits: neural tube formation by targeting fibroblast growth factor 18 (FGF18) located on chromosome 5q35.1 (32); and cell growth and endothelial migration by targeting mitogenactivated protein kinase kinase kinase 3 (MAP3K3) through the AKT-NF- $\mathrm{B}$ pathway whose genes are located on chromosomes 17q23.3 (MAP3K3), 14q32.33 (AKT serine/threonine kinase $1(A K T)), 10 q 24.31$ (component of inhibitor of nuclear factor kappa B kinase complex (IKK1)), 8p11.21 (inhibitor of nuclear factor kappa $\mathrm{B}$ kinase subunit beta (IKK2)), 4q24 (nuclear factor kappa b subunit 1 (NFKB1)), and 11q13.1 (RELA proto-oncogene, NF-KB subunit (RELA)) (33). Thus, altered expression of MIR505 could be involved in the occurrence of spina bifida in the proband from the Chinese family with CGH that is associated with a deletion of Xq27.1 and insertion of 5 q35.3 (29), although it also remains possible that it is the deletion-insertion associated disruption of SOX3 itself that is responsible for spina bifida, as SOX3 dysfunction has been reported to be linked to neural tube defects in human $(24,25)$. Different mechanisms are likely to be involved in the phenotypes of the other CGH families with insertions of 4q31.22-31.23 and $6 \mathrm{p} 21.2(27,28)$, and the XX male sex reversal patient, with insertion of 1q25.2-25.3, who did not have neural tube defects (12). Thus, it seems that different types of insertions in the same locus can affect expression in other genes and thereby result in different phenotypes. Plasma biochemistry has not been reported in CGH or XX male sex reversal, and thus any co-occurrence of HPT and associated hypocalcaemia in these patients remains unknown, although such occurrence of HPT in these patients would seem unlikely as hypocalcaemic seizures are likely to have been recognized and also as XLHPT patients do not have hypertrichosis or XX male sex reversal.

In the two XLHPT families, the two deletions within Xq27.1 are of different sizes but do overlap, whilst the two insertions which both originate from 2p25.3 do not overlap, and both deletion-insertions lead to a net gain of DNA of differing amounts ( 315 kb and $\sim 46$ $\mathrm{kb})$, resulting in the same phenotype. This comparison may help to elucidate the mechanism(s) by which the deletion-insertion alters SOX3 expression (Fig. 1B). First, this may be due to loss of an enhancer or repressor from the shared missing segment of the $\mathrm{X}$ chromosome.

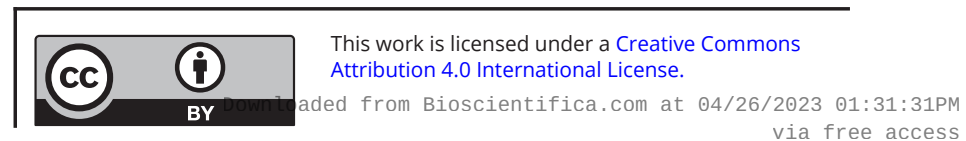


This is possible because there is overlap such that the 1.5 $\mathrm{kb}$ deletion in the IL family is contained within the $25 \mathrm{~kb}$ deletion from the MO family, but unlikely because the small $1.5 \mathrm{~kb}$ region does not contain any ultraconserved sequences. Second, this may be due to gain of an enhancer or repressor within the inserted DNA. This is possible because most of the inserted DNA is non-coding, but unlikely because the two inserted regions in the two families do not overlap, and there is a low probability that two different insertions would both result in the same subtle effect on timing of SOX3 expression in the developing parathyroid glands, as is postulated in these two families. Third, the deletion-insertion may move an enhancer or repressor away from SOX3. This is possible because both deletion-insertions cause net gain of DNA. One such regulatory element, which has been shown to be a likely enhancer of gene expression in zebrafish, is uc482 (16), although uc482 has not been shown directly to affect SOX3 expression and our studies reveal that mice lacking uc482 do not develop HPT (Fig. 4 and Table 2). However, there are also 4 other ultraconserved elements in the region between SOX3 and uc482, all of which would also be affected by the interstitial deletioninsertions (16), so a combinatorial loss of these elements may be required to alter SOX3 expression and cause HPT. Finally, the deletion-insertion may disrupt a topological associated domain (TAD), which represents a fundamental three-dimensional evolutionarily conserved genomic structural unit that directs regulatory elements to their promoters and insulates them from other genes $(34,35)$. Examination for the locations of TAD boundaries on the $\mathrm{X}$ chromosome in human non-parathyroid cell types using Hi-C chromatin interaction data did not identify TAD boundaries between the SOX 3 and ATP11C genes, with the nearest TAD boundary being located approximately $135 \mathrm{~kb}$ upstream of SOX3 (36). It is therefore unlikely that the deletion/insertion involving chromosomes Xq27.1 and 2p25.3 altered an existing TAD boundary on the X chromosome, although the possibility that the inserted chromatin may have resulted in the generation of a new TAD boundary to alter SOX3 expression cannot be excluded.

SOX3 expression was not altered by the Xq27.1/2p25.3 deletion-insertion in EBV-lymphoblastoid cells from our XLHPT patients (Fig. 2), and this may or may not reflect the situation in developing parathyroid cells. However, absence of Sox3 expression that would occur in parathyroids of mutant mice with deletion of Sox3 did not result in hypocalcemia or HPT in Sox $3^{-/ Y}$ mice (Fig. 3 and Table 1). Thus, this result indicates that complete loss of
Sox3 expression is unlikely to cause HPT, and that XLHPT is likely to be due to a more complex mechanism.

Nevertheless, a role for SOX3 in parathyroid development is highly likely as Sox3 expression has been detected in developing mouse parathyroid glands between E10.5 and E15.5 (8). However, the absence of any decrease in parathyroid size or development of HPT in mice lacking Sox3, even when challenged with a low calcium diet lacking vitamin $\mathrm{D}$, indicates that loss of Sox3 alone is not sufficient to cause HPT and that other SOX family transcription factors may compensate for loss of SOX3. Indeed, SOX proteins, which are arranged into groups designated $\mathrm{A}-\mathrm{H}$, compensate for each other within the same group. For example, two members of the SOXF group, SOX17 and SOX18, compensate for each other in developing vascular endothelial cells (37). SOX3 is a member of the SOXB1 group, which also includes SOX1 and SOX2, and all three members share significant protein sequence homology, which is at its greatest ( 95\%) within the high mobility group (HMG) DNA-binding domain (38). Furthermore, these SOXB1 members have overlapping expression patterns in the CNS (38), and despite expression of Sox3 throughout the developing CNS, Sox3 null mice develop specific defects only in the hippocampus, corpus callosum and hypothalamus, and it is therefore postulated that partial compensation by SOX1 and/or SOX 2 may prevent a more severe neurological phenotype in Sox3 null mice $(19,39)$. Indeed, redundancy between SOX2 and SOX3 has been shown for morphogenesis of the second pharyngeal arch during development in mice (39). The related SOXB1 factor, SOX19B, also acts redundantly with SOX3 in restricting WNT signalling to the organiser during CNS development and dorsoventral patterning (40).

The absence of HPT in Sox $3^{-/ Y}$ and Sox $3^{+/-}$mice indicates that loss of Sox 3 expression is not the underlying mechanism in XLHPT. Altered expression of Sox3 in three other ways could potentially be considered as possible mechanisms for XLHPT. First, the deletion-insertions may result in Sox3 overexpression. However, this seems unlikely, as patients with SOX3 duplications have been reported to have hypopituitarism, mental retardation, and XX male sex reversal, which are not features of XLHPT $(24,41,42)$. The other two possible mechanisms are that Sox 3 could either be expressed inappropriately early in the developing pharyngeal pouches, or that there might be inappropriate continued expression after the window in which Sox3 would normally be expressed. Sox3 expression in the mouse is detected in developing parathyroid glands at E10.5, E13.5, and E15.5, but not
This work is licensed under a Creative Commons Attribution 4.0 International License. ded from Bioscientifica.com at 04/26/2023 01:31:31PM 
at E18.5, indicating that the timing of Sox3 expression is likely to be important, as has been shown for other SOX proteins during organogenesis. For example, SRY expression in somatic cells of the male genital ridge has a critical expression window of only $\sim 6$ hours, during which its expression must reach a certain threshold level to trigger Sertoli cell differentiation (43). Consistent with this hypothesis, we could not demonstrate altered SOX3 expression in lymphoblastoid cells from XLHPT patients, which might not be representative of SOX3 time and/or tissue specific expression, as for example in the parathyroid glands. Investigation of a temporospatial effect on SOX3 expression in developing parathyroid glands is not possible in XLHPT patients, and will require a mouse model engineered to harbour the appropriate chromosomal rearrangements.

The lower plasma urea and creatinine concentrations in the wild-type and mutant Sox 3 mice, which are on a MF1 outbred background when on the low calcium and vitamin $\mathrm{D}$ diet (low diet) is interesting and likely to be a strain specific response to this dietary challenge. Thus, the plasma urea and creatinine concentrations did not decrease in response to the challenge with the low calcium and vitamin $\mathrm{D}$ diet, in the wild-type and mutant $u c 482$ mice (Fig. 4E and F), which are on a C57Bl/6 background, and in previously reported wild-type and mutant Gata3 mice, which were on a FVB/N background, (21). The findings of a decreased plasma urea and creatinine concentrations in both wild-type and mutant Sox3 mice, but not in wild-type or mutant uc482 and Gata3 mice, indicate that these decreased plasma concentrations are not mutant dependent, but instead are strain-specific and may involve modifier genes that influence urea and creatinine metabolism. In addition, the observed changes in creatinine metabolism due to low vitamin D in the MF1 strain (Fig. 3) are similar to that reported in healthy populations (without chronic kidney diseases) from Taiwan and Spain, in whom low dietary vitamin D was found to correlate with low plasma creatinine concentrations $(44,45)$.

In conclusion, XLHPT does not result from the absence of expression of SOX3 or absence of the regulatory element $u c 482$. Instead, the interstitial deletion-insertions likely have other effects on the temporospatial expression of SOX3 in the developing parathyroid glands.

\section{Declaration of interest}

The authors declare that there is no conflict of interest that could be perceived as prejudicing the impartiality of the research reported.

\section{Funding}

This work was supported by the Medical Research Council, UK (grant numbers G9825289 and G1000467), MRC PhD Studentships (K U G, S M M), Wellcome Trust Senior Investigator Award (R V T), Cancer Research UK, the Wellcome Trust (grant number FC001107), and Shriners Hospitals for Children.

\section{Author contribution statement}

Study design: $R L B, R \vee T$; study conduct and data collection: $K \cup G, I V G$, S M M, S E P, K G K, M S, M R B, M A N, P T C, B F, T H; data analysis and interpretation: $K \cup G, I V G, S M M, S E P, K G K, M S, K R, M R B, M A N$, $B F, T H, M P W, R L B, R \vee T$; drafting manuscript: $K \cup G, S E P, R \vee T$; revising manuscript content and approving final version of the manuscript: $K \cup G$, I V G, S M M, S E P, K G K, M S, K R, M R B, M A N, P T C, B F, T H, M P W, $R L B, R \vee T$. R $\vee T$ takes responsibility for the integrity of the data analysis.

\section{Acknowledgements}

The authors thank $\mathrm{Dr}$ L Pennacchio (Lawrence Berkeley National Laboratory, Berkeley, CA, USA) for supplying the uc482 knockout mice.

\section{References}

1 Mannstadt M, Bilezikian JP, Thakker RV, Hannan FM, Clarke BL, Rejnmark L, Mitchell DM, Vokes TJ, Winer KK \& Shoback DM. Hypoparathyroidism. Nature Reviews Disease Primers 2017317055. (https://doi.org/10.1038/nrdp.2017.55)

2 Hendy GN, Cole DEC \& Bastepe M. Hypoparathyroidism and pseudohypoparathyroidism. In Endotext. Eds KR Feingold, B Anawalt, A Boyce, et al. South Dartmouth, MA, USA: MD Text Inc., 2000. (available at: https://www.ncbi.nlm.nih.gov/books/NBK279165/)

3 Parkinson DB \& Thakker RV. A donor splice site mutation in the parathyroid hormone gene is associated with autosomal recessive hypoparathyroidism. Nature Genetics 19921 149-152. (https://doi. org/10.1038/ng0592-149)

4 Bowl MR, Mirczuk SM, Grigorieva IV, Piret SE, Cranston T, Southam L, Allgrove J, Bahl S, Brain C, Loughlin J, et al. Identification and characterization of novel parathyroidspecific transcription factor Glial Cells Missing Homolog B (GCMB) mutations in eight families with autosomal recessive hypoparathyroidism. Human Molecular Genetics 201019 2028-2038. (https://doi.org/10.1093/hmg/ddq084)

5 Mirczuk SM, Bowl MR, Nesbit MA, Cranston T, Fratter C, Allgrove J, Brain C \& Thakker RV. A missense glial cells missing homolog B (GCMB) mutation, Asn502His, causes autosomal dominant hypoparathyroidism. Journal of Clinical Endocrinology and Metabolism 201095 3512-3516. (https://doi.org/10.1210/jc.2009-2532)

6 De Luca F, Ray K, Mancilla EE, Fan GF, Winer KK, Gore P, Spiegel AM \& Baron J. Sporadic hypoparathyroidism caused by de Novo gain-offunction mutations of the $\mathrm{Ca}(2+)$-sensing receptor. Journal of Clinical Endocrinology and Metabolism 199782 2710-2715. (https://doi. org/10.1210/jcem.82.8.4166)

7 Peden VH. True idiopathic hypoparathyroidism as a sexlinked recessive trait. American Journal of Human Genetics 196012 323-337.

8 Bowl MR, Nesbit MA, Harding B, Levy E, Jefferson A, Volpi E, Rizzoti K, Lovell-Badge R, Schlessinger D, Whyte MP, et al. An interstitial deletion-insertion involving chromosomes 2p25.3 and Xq27.1, near SOX3, causes X-linked recessive hypoparathyroidism. Journal of Clinical Investigation 2005115 2822-2831. (https://doi. org/10.1172/JCI24156)

9 Mumm S, Whyte MP, Thakker RV, Buetow KH \& Schlessinger D. mtDNA analysis shows common ancestry in two kindreds with

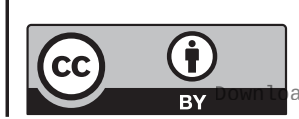

This work is licensed under a Creative Commons Attribution 4.0 International License. ded from Bioscientifica,com at 04/26/2023 01:31:31PM 
X-linked recessive hypoparathyroidism and reveals a heteroplasmic silent mutation. American Journal of Human Genetics $1997 \mathbf{6 0}$ 153-159.

10 Whyte MP \& Weldon VV. Idiopathic hypoparathyroidism presenting with seizures during infancy: X-linked recessive inheritance in a large Missouri kindred. Journal of Pediatrics 198199 608-611. (https://doi. org/10.1016/s0022-3476(81)80272-7)

11 Taylor JC, Martin HC, Lise S, Broxholme J, Cazier JB, Rimmer A, Kanapin A, Lunter G, Fiddy S, Allan C, et al. Factors influencing success of clinical genome sequencing across a broad spectrum of disorders. Nature Genetics 201547 717-726. (https://doi.org/10.1038/ ng.3304)

12 Haines B, Hughes J, Corbett M, Shaw M, Innes J, Patel L, Gecz J, Clayton-Smith J \& Thomas P. Interchromosomal insertional translocation at Xq26.3 alters SOX3 expression in an individual with XX male sex reversal. Journal of Clinical Endocrinology and Metabolism 2015100 E815-E820. (https://doi.org/10.1210/jc.2014-4383)

13 Kleinjan DA \& van Heyningen V. Long-range control of gene expression: emerging mechanisms and disruption in disease. American Journal of Human Genetics 2005 76 8-32. (https://doi. org/10.1086/426833)

14 Nesbit MA, Bowl MR, Harding B, Schlessinger D, Whyte MP \& Thakker RV. X-linked hypoparathyroidism region on Xq27 is evolutionarily conserved with regions on 3q26 and 13q34 and contains a novel P-type ATPase. Genomics 200484 1060-1070. (https://doi.org/10.1016/j.ygeno.2004.08.003)

15 Pennacchio LA, Ahituv N, Moses AM, Prabhakar S, Nobrega MA Shoukry M, Minovitsky S, Dubchak I, Holt A, Lewis KD, et al. In vivo enhancer analysis of human conserved non-coding sequences. Nature 2006444 499-502. (https://doi.org/10.1038/nature05295)

16 Navratilova P, Fredman D, Hawkins TA, Turner K, Lenhard B \& Becker TS. Systematic human/zebrafish comparative identification of cis-regulatory activity around vertebrate developmental transcription factor genes. Developmental Biology 2009327 526-540. (https://doi. org/10.1016/j.ydbio.2008.10.044)

17 Gorvin CM, Wilmer MJ, Piret SE, Harding B, van den Heuvel LP, Wrong O, Jat PS, Lippiat JD, Levtchenko EN \& Thakker RV. Receptormediated endocytosis and endosomal acidification is impaired in proximal tubule epithelial cells of Dent disease patients. PNAS 2013 110 7014-7019. (https://doi.org/10.1073/pnas.1302063110)

18 Pfaffl MW. A new mathematical model for relative quantification in real-time RT-PCR. Nucleic Acids Research 200129 e45. (https://doi. org/10.1093/nar/29.9.e45)

19 Rizzoti K, Brunelli S, Carmignac D, Thomas PQ, Robinson IC \& Lovell-Badge R. SOX3 is required during the formation of the hypothalamo-pituitary axis. Nature Genetics 200436 247-255. (https://doi.org/10.1038/ng1309)

20 Ahituv N, Zhu Y, Visel A, Holt A, Afzal V, Pennacchio LA \& Rubin EM. Deletion of ultraconserved elements yields viable mice. PLoS Biology 20075 e234. (https://doi.org/10.1371/journal. pbio.0050234)

21 Grigorieva IV, Mirczuk S, Gaynor KU, Nesbit MA, Grigorieva EF, Wei Q, Ali A, Fairclough RJ, Stacey JM, Stechman MJ, et al. Gata3-deficient mice develop parathyroid abnormalities due to dysregulation of the parathyroid-specific transcription factor $\mathrm{Gcm} 2$. Journal of Clinical Investigation 2010120 2144-2155. (https://doi. org/10.1172/JCI42021)

22 Harding B, Lemos MC, Reed AA, Walls GV, Jeyabalan J, Bowl MR, Tateossian H, Sullivan N, Hough T, Fraser WD, et al. Multiple endocrine neoplasia type 1 knockout mice develop parathyroid, pancreatic, pituitary and adrenal tumours with hypercalcaemia, hypophosphataemia and hypercorticosteronaemia. Endocrine-Related Cancer 200916 1313-1327. (https://doi.org/10.1677/ERC-09-0082)

23 Libutti SK, Crabtree JS, Lorang D, Burns AL, Mazzanti C, Hewitt SM, O'Connor S, Ward JM, Emmert-Buck MR, Remaley A, et al. Parathyroid gland-specific deletion of the mouse Men 1 gene results in parathyroid neoplasia and hypercalcemic hyperparathyroidism. Cancer Research 200363 8022-8028.

24 Bauters M, Frints SG, Van Esch H, Spruijt L, Baldewijns MM, de Die-Smulders CE, Fryns JP, Marynen P \& Froyen G. Evidence for increased SOX3 dosage as a risk factor for X-linked hypopituitarism and neural tube defects. American Journal of Medical Genetics: Part A 2014 164A 1947-1952. (https://doi.org/10.1002/ ajmg.a.36580)

25 Uguen A, Talagas M, Quemener-Redon S, Marcorelles P \& De Braekeleer M. Duplication of SOX3 (Xq27) may be a risk factor for neural tube defects. American Journal of Medical Genetics: Part A 2015 167 1676-1678. (https://doi.org/10.1002/ajmg.a.37072)

26 Bylund M, Andersson E, Novitch BG \& Muhr J. Vertebrate neurogenesis is counteracted by Sox1-3 activity. Nature Neuroscience 20036 1162-1168. (https://doi.org/10.1038/nn1131)

27 DeStefano GM, Fantauzzo KA, Petukhova L, Kurban M, TadinStrapps M, Levy B, Warburton D, Cirulli ET, Han Y, Sun X, et al. Position effect on FGF13 associated with X-linked congenital generalized hypertrichosis. PNAS 2013110 7790-7795. (https://doi. org/10.1073/pnas.1216412110)

28 Figuera LE, Pandolfo M, Dunne PW, Cantu JM \& Patel PI. Mapping of the congenital generalized hypertrichosis locus to chromosome Xq24-q27.1. Nature Genetics 199510 202-207. (https://doi. org/10.1038/ng0695-202)

29 Zhu H, Shang D, Sun M, Choi S, Liu Q, Hao J, Figuera LE, Zhang F, Choy KW, Ao Y, et al. X-linked congenital hypertrichosis syndrome is associated with interchromosomal insertions mediated by a humanspecific palindrome near SOX3. American Journal of Human Genetics 201188 819-826. (https://doi.org/10.1016/j.ajhg.2011.05.004)

30 Overton PM, Meadows LA, Urban J \& Russell S. Evidence for differential and redundant function of the Sox genes Dichaete and SoxN during CNS development in Drosophila. Development 2002129 4219-4228.

31 Dee CT, Hirst CS, Shih YH, Tripathi VB, Patient RK \& Scotting PJ. Sox3 regulates both neural fate and differentiation in the zebrafish ectoderm. Developmental Biology 2008320 289-301. (https://doi. org/10.1016/j.ydbio.2008.05.542)

32 Yang Q, Jia C, Wang P, Xiong M, Cui J, Li L, Wang W, Wu Q, Chen Y $\&$ Zhang T. MicroRNA-505 identified from patients with essential hypertension impairs endothelial cell migration and tube formation. International Journal of Cardiology 2014177 925-934. (https://doi. org/10.1016/j.ijcard.2014.09.204)

33 Tang H, Lv W, Sun W, Bi Q \& Hao Y. miR505 inhibits cell growth and EMT by targeting MAP3K3 through the AKTNFkappaB pathway in NSCLC cells. International Journal of Molecular Medicine 201943 1203-1216. (https://doi.org/10.3892/ijmm.2018.4041)

34 Dixon JR, Selvaraj S, Yue F, Kim A, Li Y, Shen Y, Hu M, Liu JS \& Ren B. Topological domains in mammalian genomes identified by analysis of chromatin interactions. Nature 2012485 376-380. (https://doi. org/10.1038/nature11082)

35 Lupianez DG, Spielmann M \& Mundlos S. Breaking TADs: how alterations of chromatin domains result in disease. Trends in Genetics 201632 225-237. (https://doi.org/10.1016/j.tig.2016.01.003)

36 Wang YL, Song F, Zhang B, Zhang LJ, Xu J, Kuang D, Li DF, Choudhary MNK, Li Y, Hu M, et al. The 3D Genome Browser: a web-based browser for visualizing 3D genome organization and longrange chromatin interactions. Genome Biology 201819 151. (https:// doi.org/10.1186/s13059-018-1519-9)

37 Matsui T, Kanai-Azuma M, Hara K, Matoba S, Hiramatsu R, Kawakami H, Kurohmaru M, Koopman P \& Kanai Y. Redundant roles of Sox17 and Sox18 in postnatal angiogenesis in mice. Journal of Cell Science 2006119 3513-3526. (https://doi.org/10.1242/jcs.03081)

38 Collignon J, Sockanathan S, Hacker A, Cohen-Tannoudji M, Norris D, Rastan S, Stevanovic M, Goodfellow PN \& Lovell-Badge R. A comparison of the properties of Sox-3 with Sry and two related genes, Sox-1 and Sox-2. Development 1996122 509-520. https://ec.bioscientifica.com https://doi.org/10.1530/EC-19-0478 (c) 2020 The authors Published by Bioscientifica Ltd

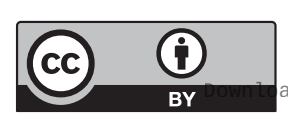

This work is licensed under a Creative Commons Attribution 4.0 International License. ded from Bioscientifica,com at 04/26/2023 01:31:31PM 
39 Rizzoti K \& Lovell-Badge R. SOX3 activity during pharyngeal segmentation is required for craniofacial morphogenesis. Development 2007 134 3437-3448. (https://doi.org/10.1242/dev.007906)

40 Shih YH, Kuo CL, Hirst CS, Dee CT, Liu YR, Laghari ZA \& Scotting PJ. SoxB1 transcription factors restrict organizer gene expression by repressing multiple events downstream of Wnt signalling Development 2010137 2671-2681. (https://doi.org/10.1242/ dev.054130)

41 Moalem S, Babul-Hirji R, Stavropolous DJ, Wherrett D, Bagli DJ, Thomas P \& Chitayat D. XX male sex reversal with genital abnormalities associated with a de novo SOX3 gene duplication. American Journal of Medical Genetics: Part A 2012 158A 1759-1764. (https://doi.org/10.1002/ajmg.a.35390)

42 Stagi S, Lapi E, Pantaleo M, Traficante G, Giglio S, Seminara S, de Martino M. A SOX3 (Xq26.3-27.3) duplication in a boy with growth hormone deficiency, ocular dyspraxia, and intellectual disability: a long-term follow-up and literature review. Hormones 201413 552-560. (https://doi.org/10.14310/horm.2002.1523)

43 Hiramatsu R, Matoba S, Kanai-Azuma M, Tsunekawa N, KatohFukui Y, Kurohmaru M, Morohashi K, Wilhelm D, Koopman P \& Kanai Y. A critical time window of Sry action in gonadal sex determination in mice. Development 2009136 129-138. (https://doi. org/10.1242/dev.029587)

44 Lee MJ, Hsu HJ, Wu IW, Sun CY, Ting MK \& Lee CC. Vitamin D deficiency in northern Taiwan: a community-based cohort study. BMC Public Health 201919 337. (https://doi.org/10.1186/s12889019-6657-9)

45 Gonzalez-Molero I, Morcillo S, Valdes S, Perez-Valero V, Botas P, Delgado E, Hernandez D, Olveira G, Rojo G, Gutierrez-Repiso C, et al. Vitamin D deficiency in Spain: a population-based cohort study. European Journal of Clinical Nutrition 201165 321-328. (https://doi. org/10.1038/ejcn.2010.265)

Received in final form 19 December 2019

Accepted 20 January 2020

Accepted Manuscript published online 21 January 2020

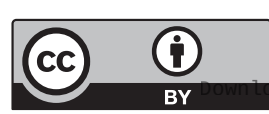

This work is licensed under a Creative Commons Attribution 4.0 International License.

ded from Bioscientifica.com at 04/26/2023 01:31:31PM 